\title{
18. STRUCTURE OF UPPER LAYER 2 IN HOLE 896A ${ }^{1}$
}

\author{
Yildirim Dilek, ${ }^{2}$ Gregory D. Harper, ${ }^{3}$ Jeffrey E. Walker, ${ }^{2}$ Simon Allerton, ${ }^{4}$ and Paola Tartarotti ${ }^{5}$
}

\begin{abstract}
Hole 896A was drilled $1 \mathrm{~km}$ southeast of Hole 504B during Ocean Drilling Program (ODP) Leg 148 to study the variability in the volcanic and chemical structure of the oceanic crust and to examine the effects of off-axis hydrothermal activity on the basement. The volcanic units cored from 195.1 to $469 \mathrm{mbsf}$ in Hole 896A consist mainly of pillow basalts with minor massive lava flows and breccias. The dominant structures encountered in these rocks are hydrothermal veins, vein faults, and breccias. Early-stage veins are steeply dipping and filled with Fe-oxyhydroxide + clay veins whereas late-stage veins are shallow dipping and filled with fibrous carbonate and clay + carbonate. Both the fibrous and intermediate-stage, nonfibrous carbonate + clay veins show shallow to moderate dips and indicate extension in many directions locally occurring within north-south striking subvertical planes, normal to the Costa Rica Rift axis. Smectite is the dominant phyllosilicate mineral in the veins. Transformation of smectite to chlorite occurs through a mixed-layered transition zone at $440.1 \mathrm{mbsf}$, probably as a result of complex interplays among the temperature, porosity, and fluid composition conditions in the crust at this depth. Vein faults with commonly oblique to reverse senses of shearing occur in the core between 334 and 406 mbsf. Extensional faults near 335 mbsf display northwest strikes with steep to vertical dips (oriented using the paleomagnetic declination) and are oblique to the Costa Rica Rift axis. The existence of a structural break at 356 mbsf near the bottom of the lithologic Unit 30 is suggested by the presence of a major change in the downhole electrical resistivity profile. The occurrence of this break nearly coincides with an abrupt change in magnetic properties of the rocks and may represent a fault zone that has facilitated high permeability of the basement in Hole 896A. Fragmentation of cooled pillow lava rims, mass wasting on the seafloor, and hydraulic fracturing beneath the seafloor appear to be responsible for development of several types of breccias in the upper part of Layer 2 .
\end{abstract}

\section{INTRODUCTION}

Hole $896 \mathrm{~A}$, located $1 \mathrm{~km}$ southeast of Hole $504 \mathrm{~B}$, is situated on a bathymetric high overlying a basement topographic high that coincides with a local heat-flow maximum (Fig. 1). It is a site of off-axis hydrothermal activity where low-temperature hydrothermal fluids are upwelling as determined during a Leg 111 site survey. Systematic structural studies of the core samples from Hole 896A have provided significant information on the structural architecture of the upper part of Layer 2 which leads to a better understanding of the structural evolution of ocean crust in the Cost Rica Rift region. In this paper we describe the occurrence, type, and nature of structures, and their downhole variation in core samples from Hole 896A recovered during Leg 148. The data presented here provide a framework to evaluate the structural evolution of upper oceanic crust in the eastern Pacific that is addressed in an accompanying paper by Harper and Tartarotti (this volume). The paper includes three main parts: the first part describes the structures in the core as observed in hand specimens and thin sections and also discusses the basement structure from geophysical measurements. The second part presents a discussion of the results of X-ray diffraction (XRD) and microprobe analyses and modeling of vein phyllosilicates to establish vein mineralogy and paragenesis. The analytical methods of the phyllosilicate study and its results are presented in the Appendixes. Downhole variations in the intensity and orientation of various structures and their comparison with Hole 504B are discussed in the third part.

\footnotetext{
IAlt, J.C., Kinoshita, H., Stokking, L.B., and Michael, P.J. (Eds.), 1996. Proc, ODP, Sci. Results, 148: College Station, TX (Ocean Drilling Program).

${ }^{2}$ Department of Geology and Geography, Vassar College, Poughkeepsie, NY 12601,U.S.A. Dilek: yidilek@vassar.edu; Walker: jewalker@vassar.edu

'Department of Geosciences, State University of New York at Albany, Albany, NY 12222, U.S.A. gdh@ csc.albany.edu

${ }^{4}$ Department of Geology and Geophysics, University of Edinburgh, The Grant Institute, West Mains Road, Edinburgh EH9 3JW, United Kingdom. simona@glg.ed.ac.uk

${ }^{5}$ Dipartimento di Geologia, Paleontologia e Geofisica, Università di Padova, Via Giotta 1, 1-35157 Padova, Italy, tar@epidote.dmp.unipd.it
}

\section{STRUCTURES IN THE CORE}

The basement rocks recovered at Hole $896 \mathrm{~A}$ consist mainly of tholeiitic basalts, which include massive and pillow lava flows, volcanic breccias, and minor dikes. Pillow lavas constitute the major part ( $57 \%$ of the drilled section) of the core, and massive lava flows and breccias together make up the remainder with breccias comprising nearly 5\% of the drilled section (Shipboard Scientific Party, 1993). Pillow lavas are characterized by curved to planar chilled and/or glassy margins, interior variolitic zones, and relatively finer grain size of the basalt compared to massive lava units. The main types of structures observed in these volcanic units include veins, vein faults and fractures, breccias, and intrusive contacts.

\section{Veins}

Veins are the most prominent structures in the core, and they represent 2 vol\% of the recovered samples from Hole 896A (Shipboard Scientific Party, 1993). Two main types of veins were observed in the core. Fibrous veins, consisting of carbonate and/or clay minerals, show a broad spectrum of width $(0.5-8 \mathrm{~mm})$ and range from planar and curvilinear to sinuous and irregular (Fig. 2). The long axes of fibers filling in the veins are commonly orthogonal to the vein walls, suggesting that the fibers track the opening direction of a vein during pure extension (Fig. 3; Cox and Etheridge, 1983). Whereas carbonate fibers extend from wall-to-wall with crystallographic continuity (e.g., Samples 148-896A-3R-1, 83-86 cm, Piece 9A, and 7R-1, 135$139 \mathrm{~cm}$, Piece 22), clay fibers are generally arranged with their $(001)$ planes orthogonal or at a high angle to the vein walls (Shipboard Scientific Party, 1993). The width of carbonate fibers commonly increases from the vein walls towards the vein center, suggesting incremental growth of fibers from the wall to the center of the veins (Ramsay and Huber, 1983; Tartarotti et al., this volume; Samples 148-896A-5R-3, 1-5 cm, Piece 1A; 7R-1, 5-8 cm, Piece 1; and 7R$1,135-139 \mathrm{~cm}$, Piece 22). The existence of clay fibers alternating with carbonate fibers and/or along the vein walls is common in fibrous carbonate veins. Fibrous clay veins locally contain inclusion 


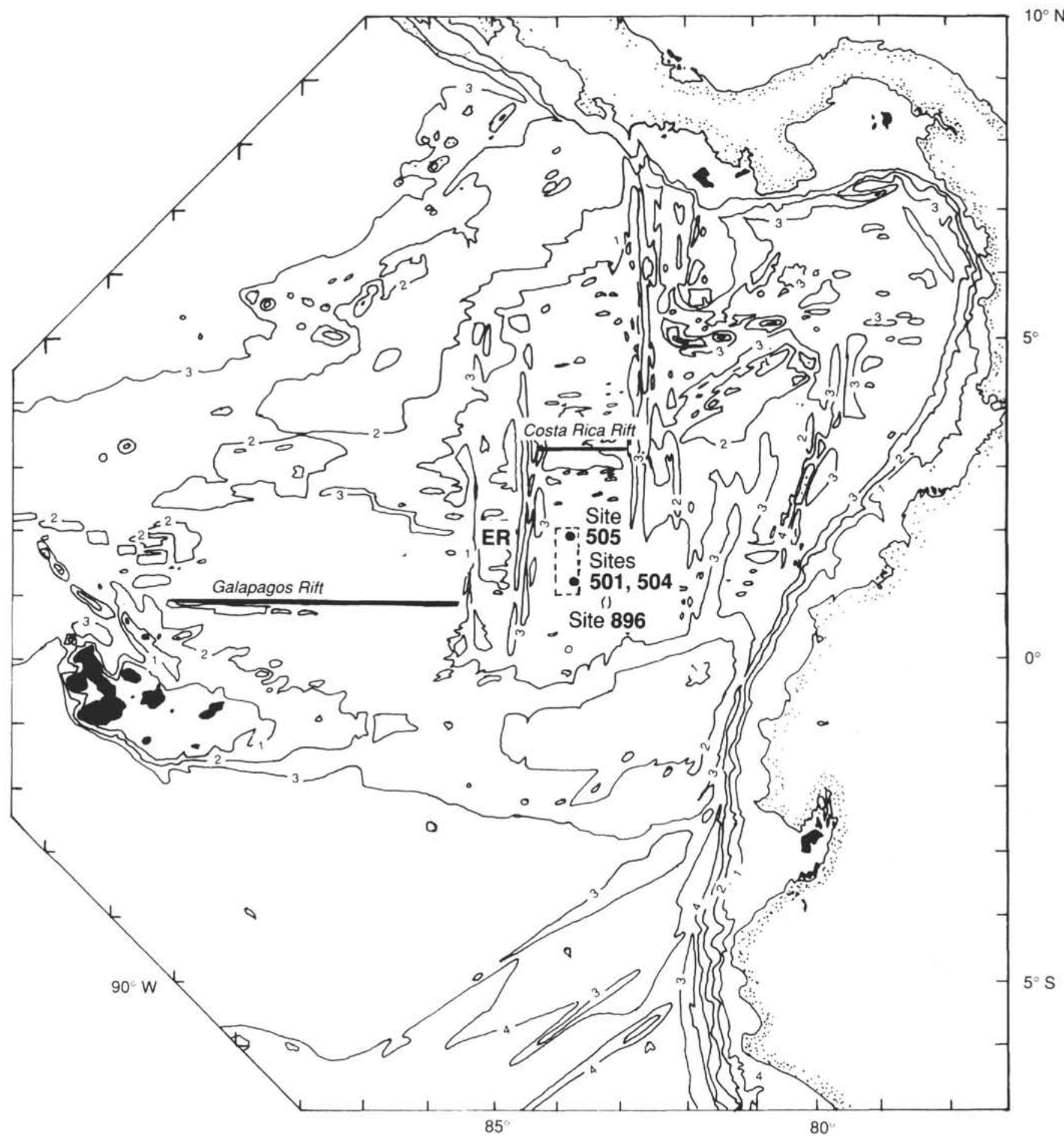

Figure 1. Location of DSDP Sites 501 and 505, DSDP/ODP Site 504, and ODP Site 896 south of the Costa Rica Rift in the eastern equatorial Pacific (after Hobart et al., 1985).

bands parallel to the veins walls and irregular suture lines along the center of the vein where fibers extending from opposite walls meet (e.g., Sample 148-896A-1R-1, 47-55 cm, Piece 11).

Nonfibrous vein assemblages include Fe-oxyhydroxide + brown clay, clay minerals alone (dark green and/or light green), blocky carbonate + clay, and clay minerals + pyrite \pm chalcopyrite (Figs. 2, 4, 5 ). The Fe-oxyhydroxide-bearing veins are generally reddish brown and are submillimetric in width. They are commonly irregular-to-sinuous in shape and show anastomosing branches. Locally, they con- tain a thin line of green clay in their center indicating that they were subsequently reopened (e.g., Sample 148-896A-17R-5, 7-16 cm). The veins filled with blocky carbonate + clay are generally thicker than fibrous veins (1-8 mm wide) and display a curvilinear to sinuous morphology. They show a "vermicular" texture with spherical aggregates; the blocky carbonate commonly consists of large crystals (up to $2 \mathrm{~mm}$ in width) arranged in a mosaic texture. Nonfibrous veins filled with clay minerals (dark and light green) are generally submillimetric in width and occur as planar to curvilinear single veins or as 


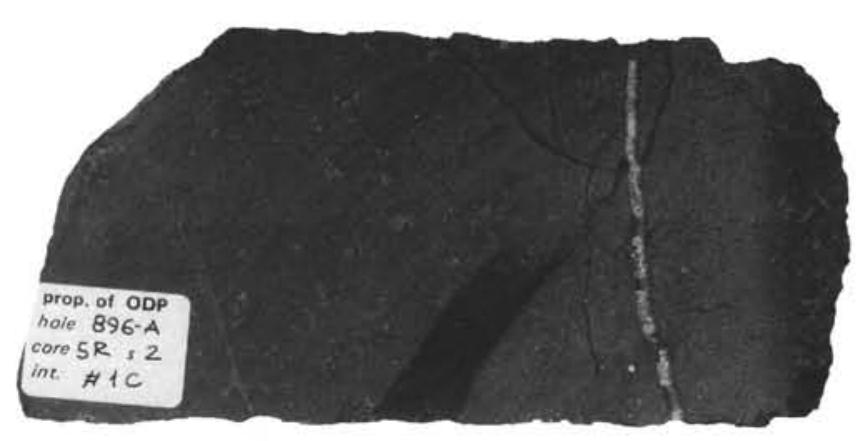

Figure 2. Crosscutting relations of a fibrous carbonate + clay vein with darkgreen clay veins. Note the alteration halo around the clay veins. Chilled margin of the pillow lava is on the right and nearly horizontal with respect to the core axis. Carbonate + clay vein is parallel to this chilled margin and also horizontal. Sample 148-896A-5R-2 (Piece 1C).

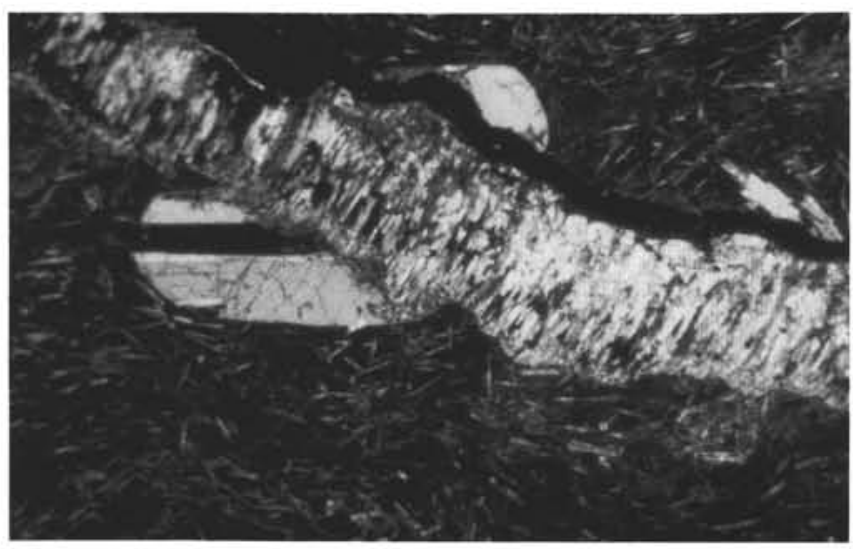

Figure 3. Fibrous carbonate + clay vein with wall-perpendicular fibers splitting a plagioclase phenocryst with no shearing or displacement. Polarized light. Scale bar is $1 \mathrm{~cm}$.

anastomosing and branching vein systems. They are particularly well developed as part of vein networks and/or incipient brecciation within and near the glassy chilled margins of pillow lavas (e.g., Sample 148-896A-10R-1, 13-45 cm; and 18R-1, 80-86 cm; Fig. 6). A single occurrence of dark-green clay + pyrite vein is also observed in Sample 148-896A-16R-3 (Piece 7).

Fibrous veins commonly display overlapping segments that locally form an en echelon pattern (Sample 148-896A-12R-1, 24-33 cm; Fig. 7). Vein tips in such overlapping segments show mainly a convergent geometry with anastomosing hairline fractures at and ahead of the convergent vein tips (Sample 148-896A-7R-1, 135-139 cm). Triple junctions and $\mathrm{T}$-shape intersections are also common between carbonate- and/or carbonate-clay-bearing veins (Fig. 8). The observed triple-junction geometry and T-shape intersections are reminiscent of thermal contraction fractures in some extrusive and intrusive rocks (Pollard and Aydin, 1988).

Changes along strike in the composition of vein-filling minerals are common in the core. Such changes seem to be spatially associated with the distribution of alteration halos, and veins entering different zones of alteration halos acquire different mineralogy (Shipboard Scientific Party, 1993). In Sample 148-896A-21R-1 (Piece 10), for example, the center of the core is composed of gray, non-oxidized basalt which is surrounded by a red-orange oxidation halo, and the submillimetric horizontal (with respect to the core axis) veins within the gray zone are filled mainly with fibrous aragonite whereas they are composed of light-green clay with little or no carbonate in the red oxidized zone. These veins are in turn cut by a subvertical, fibrous carbonate vein that diagonally traverses the alteration zone.

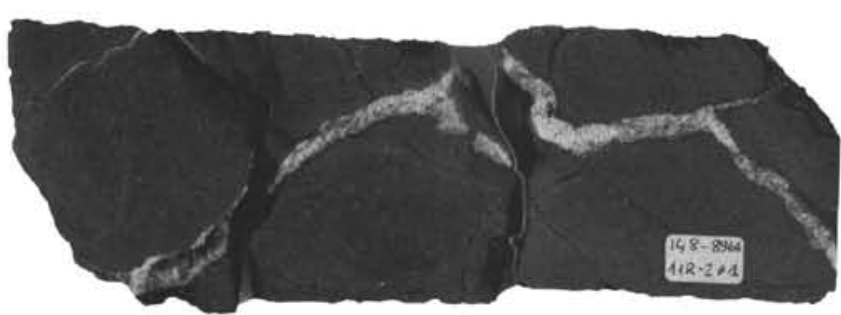

Figure 4. Blocky carbonate + clay (large one) and fibrous carbonate veins. Note the overlapping segments of thin, fibrous carbonate veins with convergent tips on the left-hand side. Sample 148-896A-1IR-2 (Piece 1).

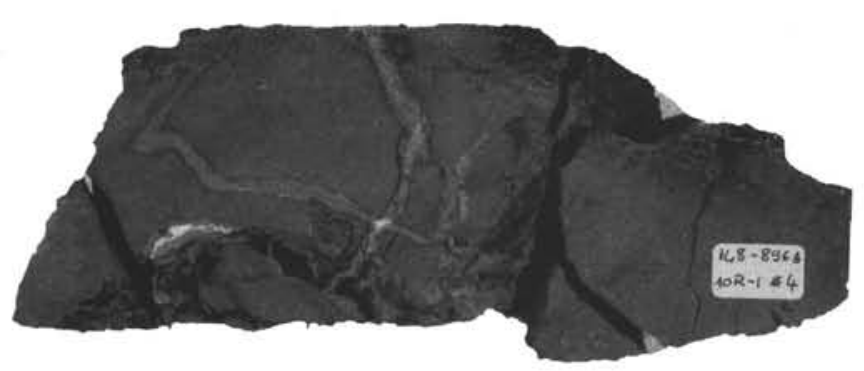

Figure 5. Intersecting vermicular clay veins. Sample 148-896A-10R-1 (Piece 4).

Fibrous vs. nonfibrous nature of the veins and the textural arrangement of vein-filling minerals point to significant differences in the evolution mechanisms of veins (Shipboard Scientific Party, 1993; Tartarotti et al., this volume). Fibrous vein systems include antitaxial, composite, and stretched crystal fiber veins (Ramsay and Huber, 1983), are commonly filled with carbonate and carbonate + clay minerals, and show internal structures and geometric features suggesting a growth by the crack-seal mechanism (Tartarotti et al., this volume). The morphology and texture of these fibrous veins and their evolution via crack-seal mechanism are described in detail in an accompanying paper in this volume (Tartarotti et al., this volume). The presence in some samples of plagioclase and/or clinopyroxene grains split by stretched crystal fiber veins without any evidence of shearing indicates pure extension (e.g., Samples 148-896A-4R-1, 5-8 cm, Piece 1; and 6R-3, 6-9 cm, Piece 1; Fig. 3).

Crosscutting relations between different generations of veins and vein systems suggest that $\mathrm{Fe}$-oxyhydroxide + brown clay veins are generally the oldest whereas fibrous veins are the youngest (Shipboard Scientific Party, 1993). Thin, nonfibrous and nonvermicular dark-green clay veins and blocky carbonate/vermicular clay veins constitute intermediate vein generations. These intermediate vein generations are commonly spatially associated with incipient breccias that show a "jigsaw puzzle" fabric. As the brecciation advances, the vein networks are occupied by thick patches of vermicular clay and/or blocky carbonate minerals replacing dark-green clay minerals. Generally, dark-green clay minerals display oxidation halos around them whereas fibrous and blocky carbonate veins are free of such alteration fronts (Fig. 2). Carbonate veins commonly traverse oxidation halos indicating that oxidative alteration in basaltic rocks predated the development of carbonate-bearing veins.

\section{Vein Orientation and Distribution}

Several core samples and hence a subset of veins have been oriented using the stable paleomagnetic declination. True-dip histograms of different vein generations that are paleomagnetically oriented are shown in Figure 9. The histogram of rare $\mathrm{Fe}$-oxyhydroxide + clay veins shows that the majority of these early veins have steep dips between $70^{\circ}$ and $90^{\circ}$. Considering that the Fe-oxyhydroxide veins are more common in massive lava units, they may represent 


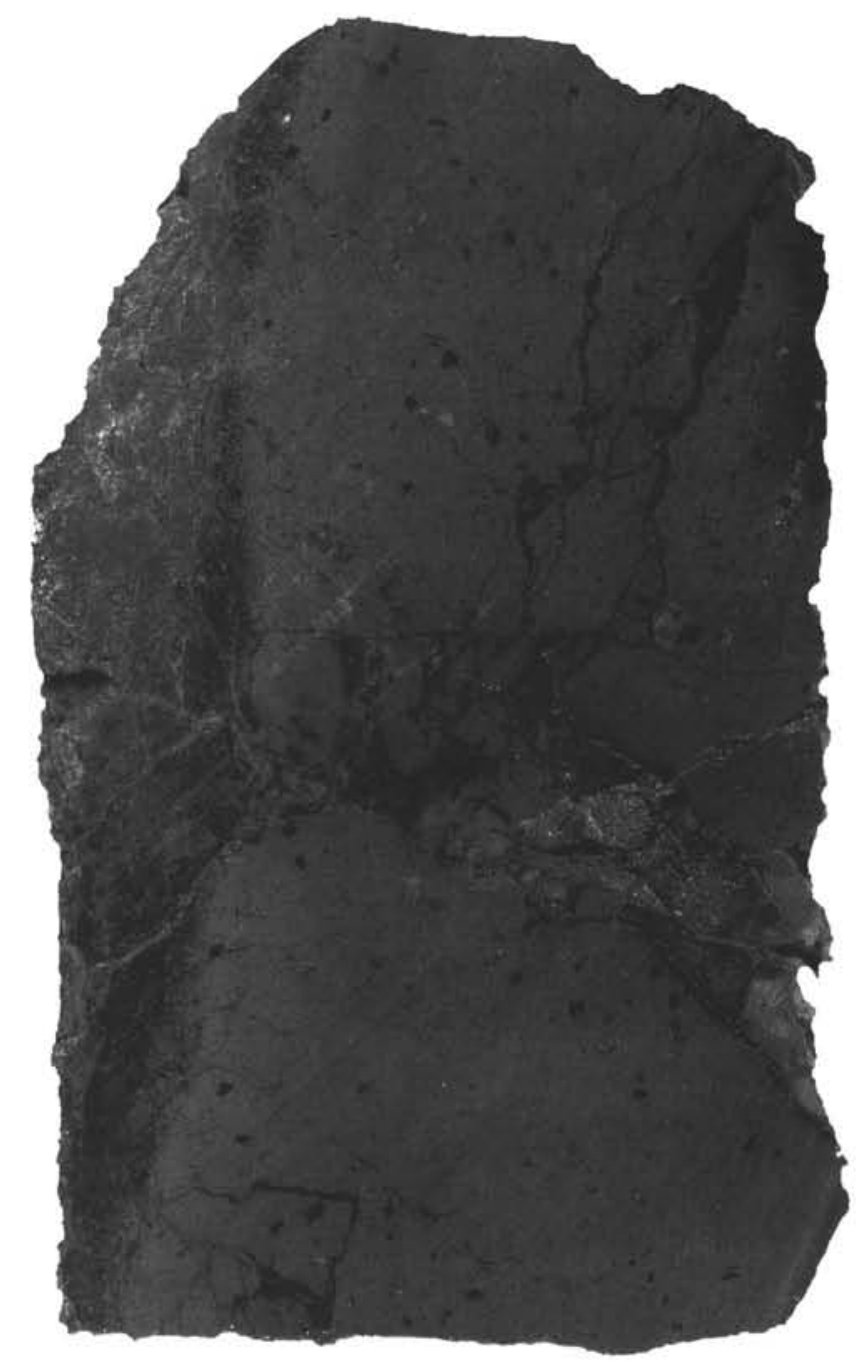

Figure 6. Network of dark-green clay veins and incipient brecciation near the vertical chilled margin of a pillow lava. Sample 148-896A-18R-1 (Piece 6A).

steeply dipping cooling joints that were subsequently filled with vein minerals. Dip angles of the nonfibrous, dark-green clay veins are scattered, but most of these intermediate-stage veins have dips ranging between $20^{\circ}$ and $80^{\circ}$. These veins are commonly spatially associated with complex vein networks within and near the chilled margins of pillow lavas and pillow rims, and their attitudes may hence mimic the shapes and orientations of pillow margins resulting in a considerable scatter in their dip angles. Clay-carbonate composite veins, which are mostly fibrous types, exhibit a faint bimodal distribution of dip angles with a clear majority below $40^{\circ}$. More than half of these veins have shallow dips between $15^{\circ}$ and $40^{\circ}$ and contain fibers nearly perpendicular to the vein walls. The carbonate veins, including both fibrous and blocky types, have scattered dips with a strong peak between $45^{\circ}$ and $65^{\circ}$. This peak of the carbonate veins corresponds to the weak second peak displayed by the clay-carbonate veins. Late-stage fibrous veins with relatively shallower dips appear to have formed by extension normal to the vein walls, and they are interpreted to have resulted from a succession of "crackseal" increments during extension caused by fluid overpressure.

Equal-area stereographic projections of paleomagnetically oriented veins and vein groups are shown in Figure 10. Although the earlystage, Fe-oxyhydroxide + clay veins have random attitudes with generally steep dips, the intermediate-stage clay and clay + carbonate veins display strong maxima corresponding to shallow dips, in addi-

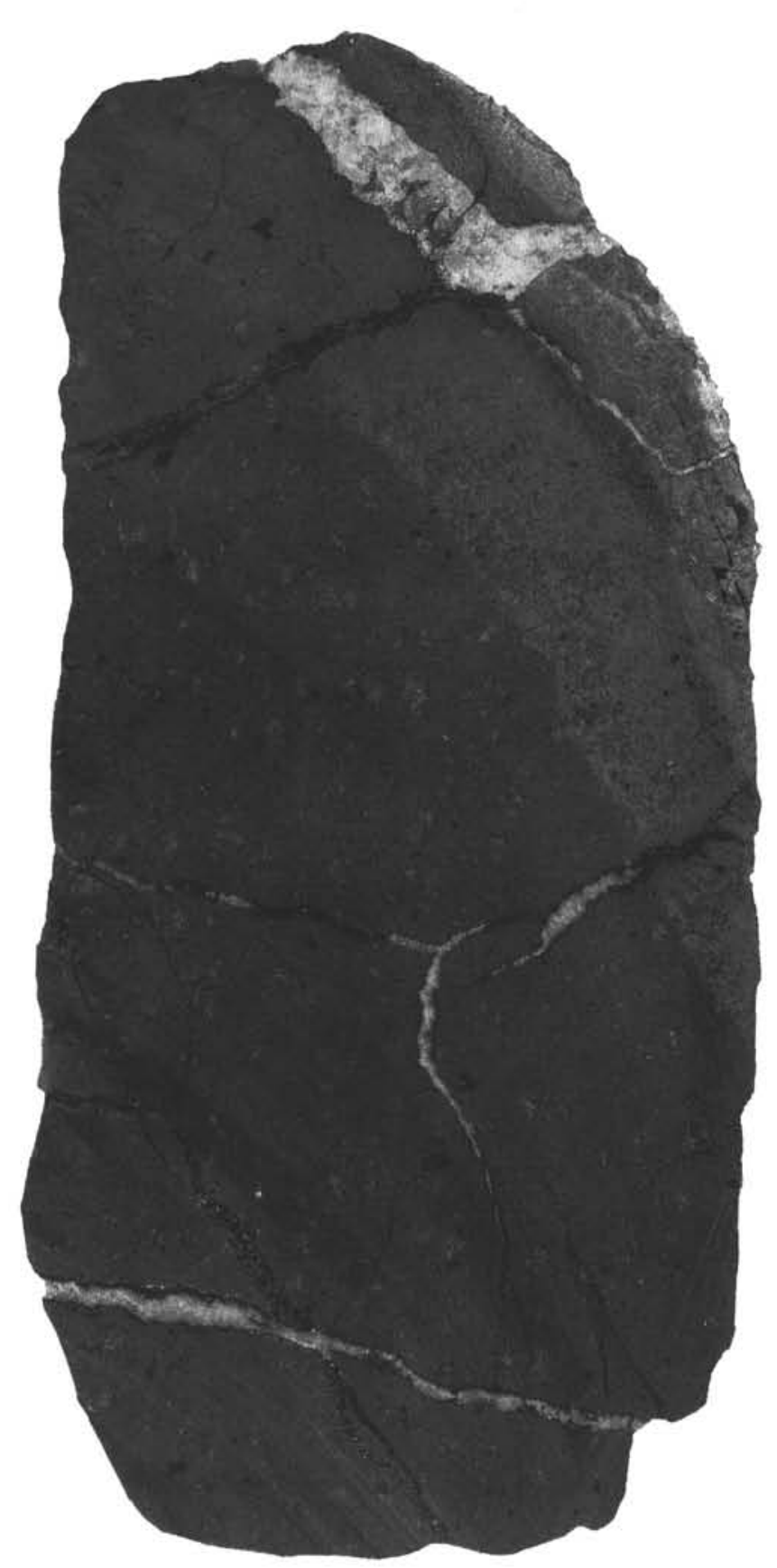

Figure 7. Triple junction and overlapping segments of fibrous carbonate + clay veins in a pillow lava. Sample 148-896A-7R-1 (Piece 7).

tion to weak to moderate north-northeast striking girdles. Clay veins, however, show considerable scatter implying extension in all directions during the intermediate-stage vein generation. The pronounced north-northeast striking girdle in the contour diagram of the mostly fibrous clay + carbonate veins points to a distinctly non-random orientation of these extensional veins. Carbonate veins show a nearly north-south striking, broad girdle with moderate to shallow dips implying that extension occurred mostly within north-south striking planes (Fig. 10D). This interpretation is consistent with the orientation of nonfibrous clay-carbonate vein networks in Sample 148896A-28R-2 (Piece 1) (Fig. 11). Poles to seven veins in this piece plot along a steeply dipping great circle indicating that extension occurred in many directions within a subvertical plane striking nearly northsouth, normal to the Costa Rica Rift axis. Most veins filled with ver- 


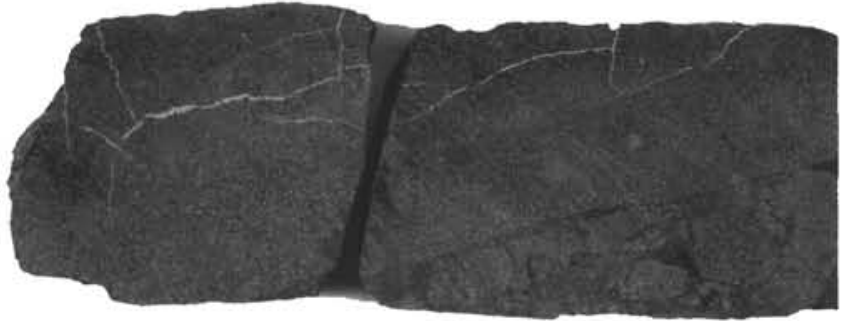

Figure 8. Thin, fibrous carbonate veins with T-intersections and overlapping segments in a massive lava composed of moderately phyric plagioclaseolivine basalt. Note the sharp boundary between the brecciated section and the intact basalt. The reddish orange-colored alteration front is restricted to the intact part of the sample. Sample 148-896A-2IR-2 (Pieces 8A and 8B).
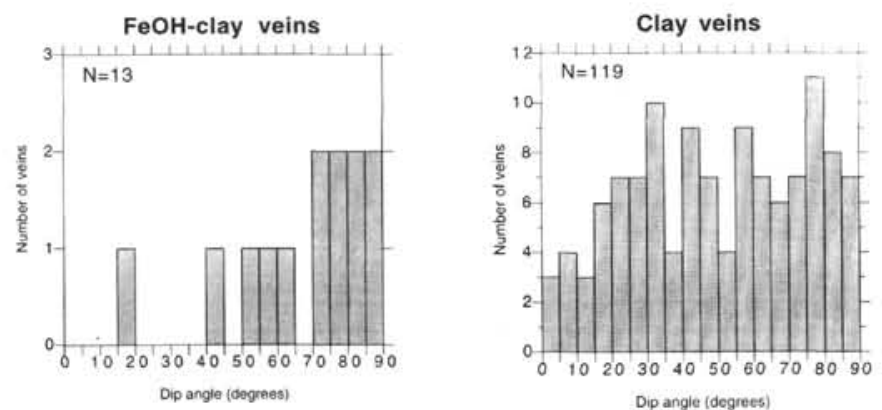

Clay-carbonate veins
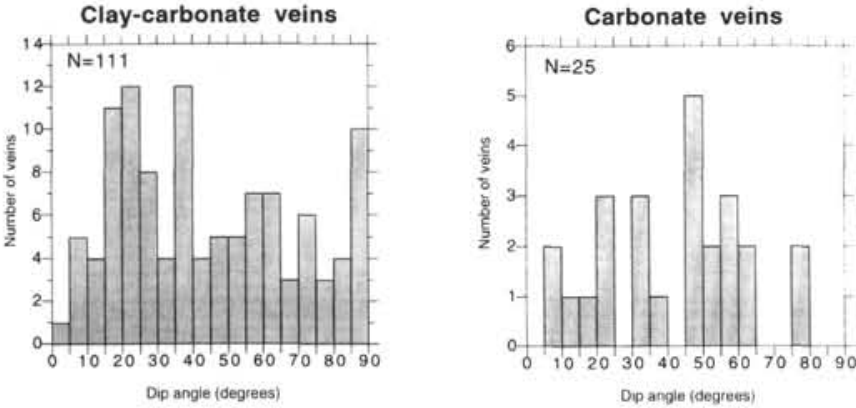

Figure 9. Histograms of paleomagnetically corrected true dips of main vein types with different mineral compositions.

micular clay and blocky carbonate minerals strike west-northwest although a steeply dipping set of veins strikes northeast (Fig. 12). Steeply dipping breccia and dike margins also display a bimodal direction in strike similar to steep veins. Fibrous veins with wall-orthogonal fibers do not show a clear pattern, but in general they seem to have shallow dips (Fig. 13). Figure 14 shows three equal area plots of poles to fibrous veins in individual pieces. Figure 14A is for fibers from three veins meeting in a triple junction in Sample 148-896A16R-2 (Piece 8) and shows extension occurring in three directions within a plane (not oriented paleomagnetically). Figure 14B shows poles to six fibrous veins (Sample 148-896A-6R-2, Piece 8) that fall along a vertical plane. This indicates extension in many directions, but all directions lie in this vertical plane. Figure $14 \mathrm{C}$ shows poles to eight fibrous veins and fibers in Sample 148-896A-16R-2 (Piece 1). Fibers were measured using a binocular microscope and are essentially normal to vein walls. The fibrous veins in this sample lie along two great circles one of which is shown here.

\section{Vein Faults and Fractures}

Most of the observed open fractures in basaltic rocks recovered from Hole $896 \mathrm{~A}$ occur along the clay-bearing veins. Several incipient type, discontinuous fractures in oriented samples have dips ranging
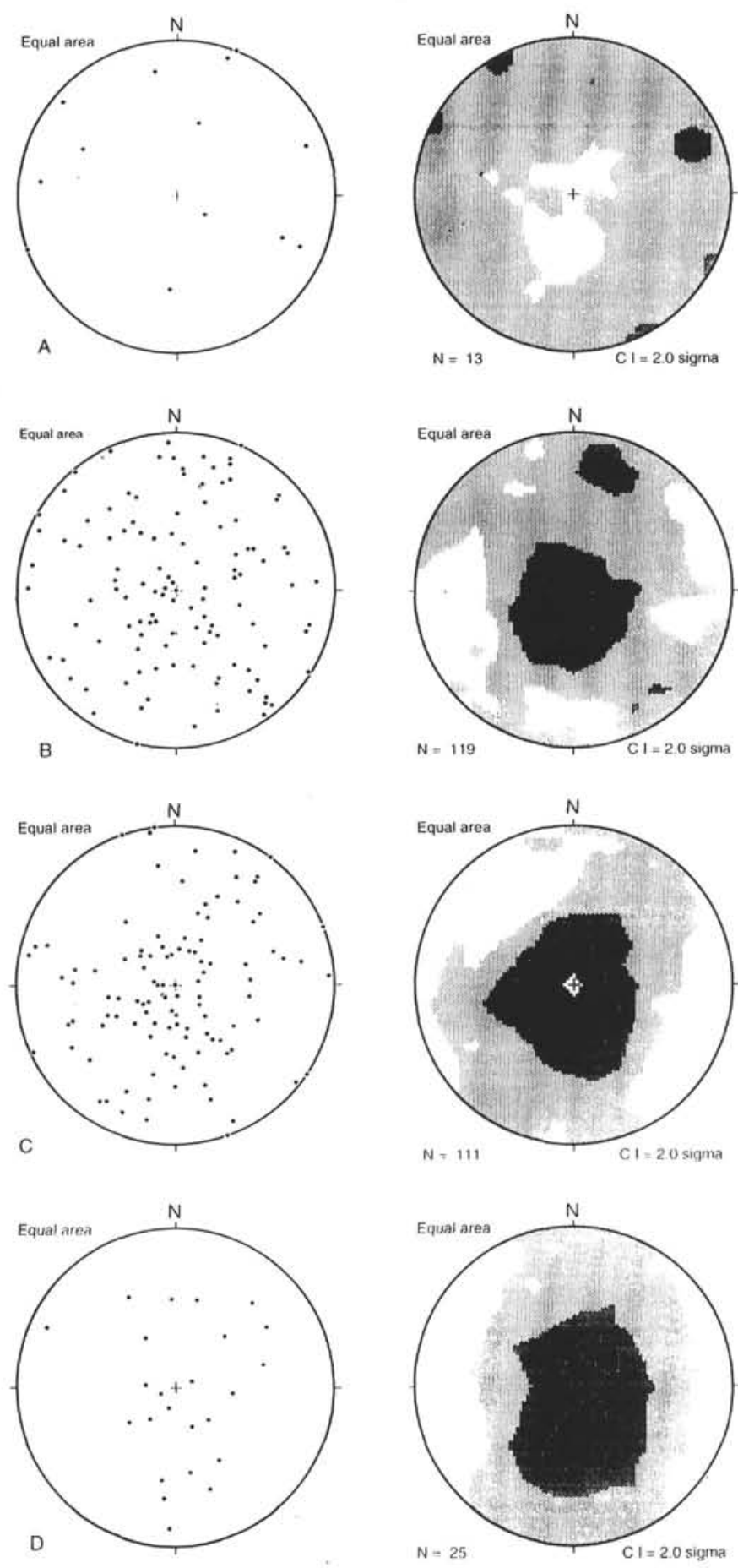

Figure 10. Equal-area stereographic projections and Kamb-contour diagrams of poles to main vein types that are paleomagnetically oriented. A. Fe-oxyhydroxide + clay veins. B. Dark to light-green clay veins. C. Carbonate + clay veins. D. Carbonate veins. $\mathrm{CI}=$ Contour interval.

from $4^{\circ}$ to $88^{\circ}$. One probable drilling-induced "disking" fracture recovered in Sample 148-896A-6R-2 (Piece 10A) has a saddle axis with a trend of $126^{\circ}$ (after paleomagnetic reorientation), which nearly coincides with the BHTV defined breakout mode from nearby Hole 504B (Morin et al., 1990).

Numerous vein faults occur in the core between 334 mbsf and 406 mbsf (Table 1). These vein faults have slickenfibers oblique to the vein walls, and the geometries of step structures suggest mostly oblique to reverse shearing along them. Figure 15 displays two equal 


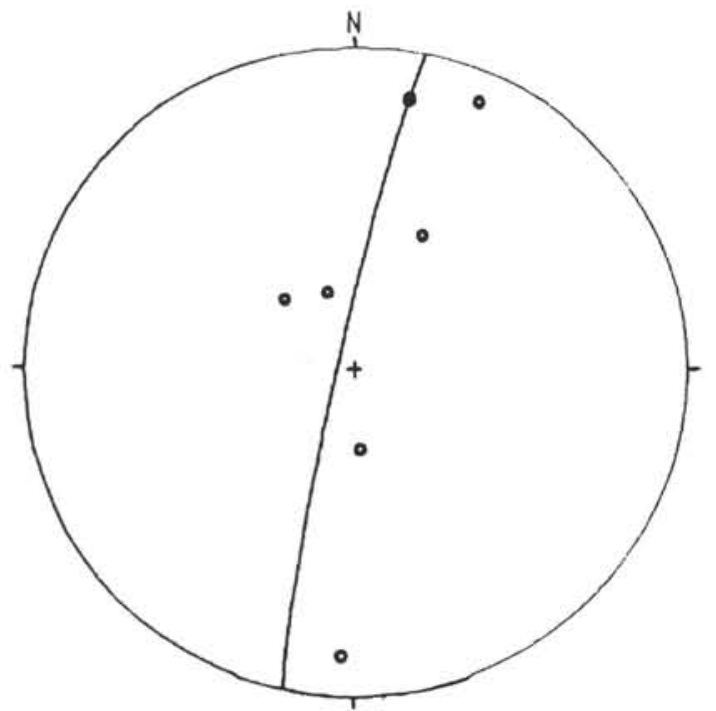

$\begin{array}{ll}\text { Projection } & \text { Schmid } \\ \text { Number of sample points } & 7 \\ \text { Great circle azimuth } & 192.2 \\ \text { Great circle plunge } & 85.9 \\ \text { 1st Eigenvalue } & 0.607 \\ \text { 2nd Eigenvalue } & 0.358 \\ \text { 3rd Eigenvalue } & 0.034 \\ \text { LN (E1/E2) } & 0.529 \\ \text { LN (E2/E3) } & 2.342 \\ \text { \{LN(E1/E2)\} / \{LN(E2/E3)\} } & 0.226 \\ \text { Spherical variance } & 0.3502 \\ \text { Rbar } & 0.6498\end{array}$

Figure 11. Poles to a nonfibrous carbonate + clay vein network in Sample 148-896A-28R-2 (Piece 1). All seven veins have similar strikes; they plot along a steeply dipping great circle.

area stereonets showing pieces that have faults with fibrous slickensides along with fibrous extension veins with orthogonal fibers. The data for these faults are given in Table 1 . The fibrous extension veins and faults in Sample 148-896A-16R-1 (Piece 9) all strike to the northwest with steep to vertical dips (all poles plot on great circle not shown here). These faults are oblique to the direction of extension along the Costa Rica Rift axis. The two faults in Sample 148-896A22R-3 (Piece 2) are normal faults dipping at $56^{\circ}$ and $90^{\circ}$ that strike subperpendicular and subparallel, respectively, to the Costa Rica Rift axis.

\section{Breccias}

Breccias and brecciated basaltic rocks are abundant in the core from Hole $896 \mathrm{~A}$, and three main types of breccias are distinguished by their texture and fabric (Shipboard Scientific Party, 1993). Hyaloclastite breccias commonly occur at or near pillow-lava rims and consist of clasts of volcanic glass and glass shards surrounded by a matrix composed of clay minerals and altered glass (Fig. 16).

A second type of breccia is composed of angular to subangular and poorly sorted clasts of basalt cemented by clay minerals and rare carbonates (Fig. 17). These breccias occur within both pillowed and massive lava units and generally have sharp contacts with unbrecciated basalt (Fig. 8). The clast size ranges from $1 \mathrm{~mm}$ to $10 \mathrm{~cm}$; most clasts contain veins and alteration and oxidation zones that are truncated at their edges indicating that brecciation postdated the development of alteration, oxidation, and veining (e.g., Samples 148-896A20R-1, Pieces 17 and 18; 27R-2, Piece 5B; and 27R-2, Piece 7). This second type of breccia is particularly abundant in Cores 148-896A18R, 20R, 21R, 27R, 28R, and 30R all below $350 \mathrm{mbsf}$. A $25-\mathrm{cm}-$
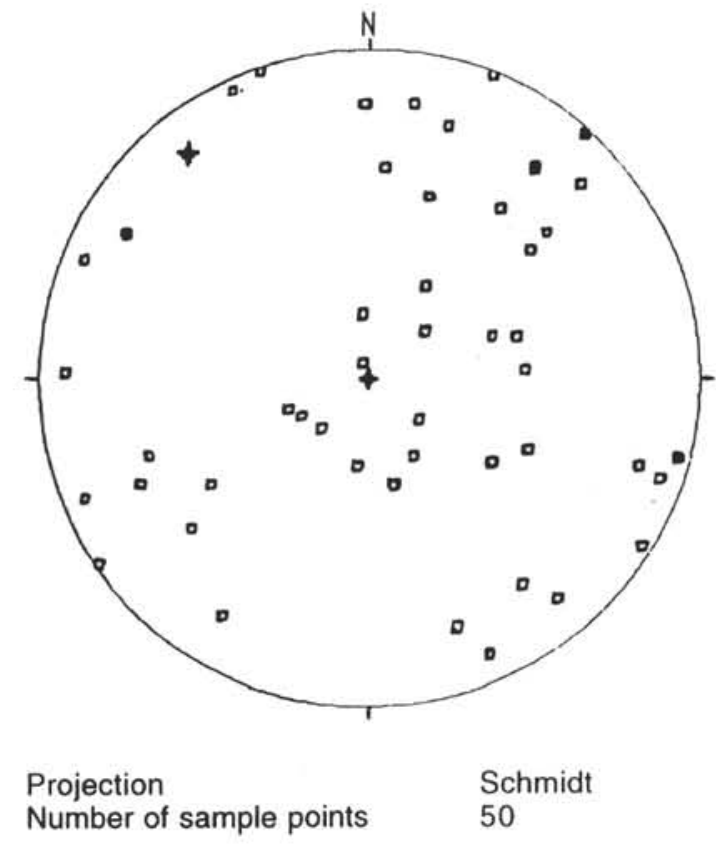

- Vermicular clay and blocky carbonate veins
- Dike margin
- Breccia margins

Figure 12. Poles to vermicular clay + blocky carbonate veins, dike margins, and breccia margins. Most veins strike west-northwest whereas a subset of veins shows northeast strikes. Dike and breccia margins dip steeply and show bimodal direction in strike.

thick interval of this breccia type occurs in the lithologic Unit 30 around $355 \mathrm{~m}$ at depth and just above a narrow zone of intense fracturing at 356 mbsf as detected from downhole measurements and electrical images (see the section on basement structure from geophysical measurements below; Larouzière et al., this volume). The poorly sorted nature of these breccias, the lack of preferred orientation of clasts and of bending or cracking of mineral grains in the matrix, and the lack of a planar fabric in the matrix rule out formation by frictional faulting. Harper et al. (this volume) suggested that this breccia type might have resulted from dilational faulting, and that it thus has a tectonic origin rather than sedimentary.

The third type of breccia is characterized by a "jigsaw puzzle" fabric in which the clasts can be fit back together (Fig. 18; Shipboard Scientific Party, 1993). The interstices are generally filled with hydrothermal smectite and carbonate minerals. Incipient breccias are less fragmented and display complex networks of veins within otherwise intact basalt (e.g., Samples 148-896A-23R-2, Piece 7; and 27R1 , Piece 3 ). The most common veins in these networks are filled with dark-green clay, but locally thick patches of vermicular clay and/or blocky carbonate minerals may also occur (e.g., Sample 148-896A23R-1, Piece 15). Advanced stages of fragmentation during brecciation seems to have produced basaltic clasts "floating" in a matrix of blocky carbonate and vermicular clay (Fig. 19). The internal fabric of these breccias suggests an in situ formation with fragmentation of basaltic rock along vein networks. The origin and possible mechanisms of the "jigsaw" brecciation are discussed in an accompanying paper in this volume (Harper and Tartarotti, this volume).

\section{Intrusive Contacts}

Two intrusive contacts were recovered between relatively coarsegrained massive lava units and microcrystalline to cryptocrystalline rocks in Sections 148-896A-21R-2 (Pieces 9B and C) and 22R-4 


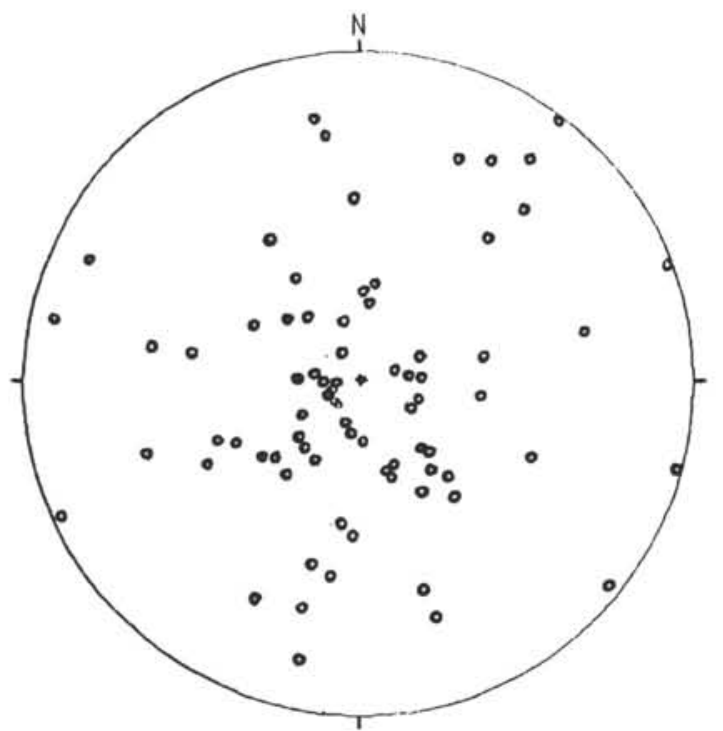

Projection Number of sample points

Schmidt 78

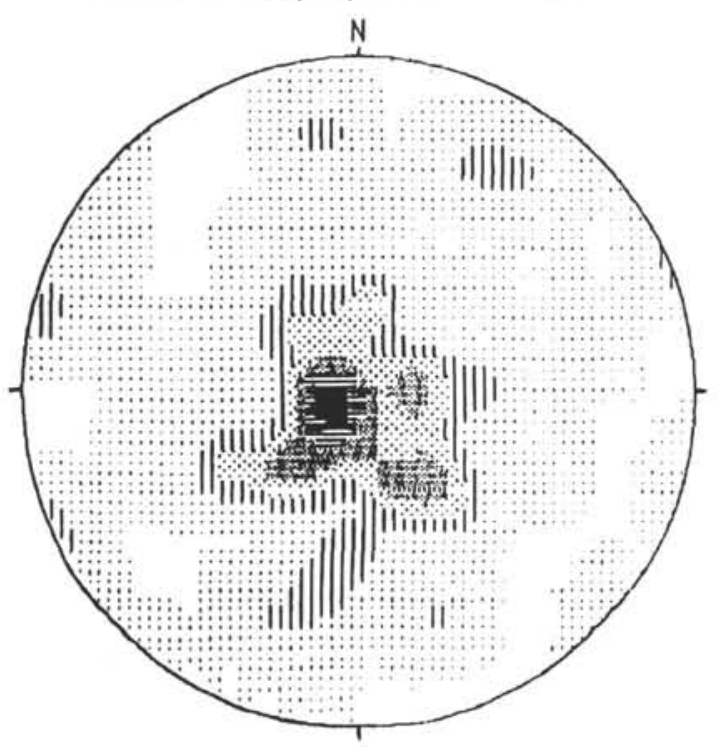

Spherical Gaussian function Number of sample points

78

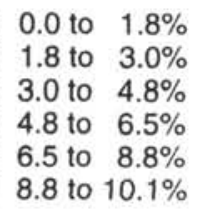

Figure 13. Stereographic projection and Kamb-contour diagram of fibrous veins with wall-perpendicular fibers. Most fibrous veins display shallow dips.

(Pieces 3-5) (Shipboard Scientific Party, 1993). These moderately planar and steeply dipping $\left(74^{\circ}-78^{\circ}\right)$ contacts are interpreted as dike margins because they lack the obvious glass and variolitic textures characteristic of chilled pillow margins. Chilled dike margins are generally brecciated and fragmented. The chilled margin in Sample

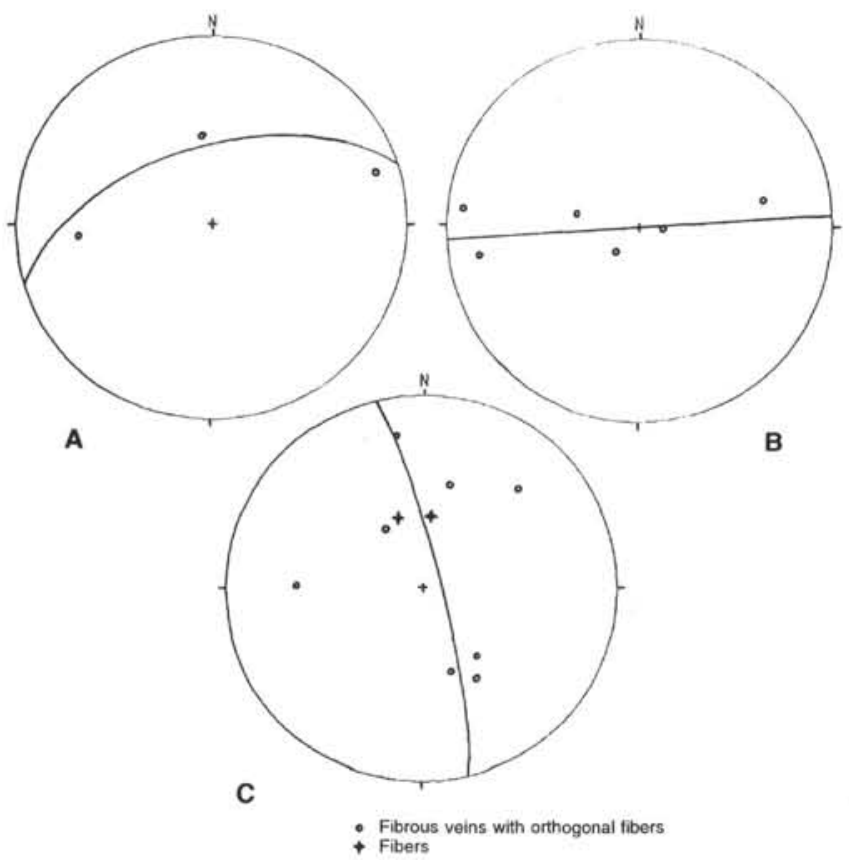

Figure 14. Stereographic projection of poles to fibrous veins in individual pieces of different core samples. Most veins lie along great circles. A. Sample 148-896A-16R-2 (Piece 8) (working half). B. Sample 148-896A-6R-2 (Piece 8) (working half). C. Sample 148-896A-16R-2 (Piece 1). See text for discussion and interpretation.

148-896A-21R-2 (Piece 9B), for example, is separated from the massive host rock by a $0.5-\mathrm{cm}$-thick microbreccia composed of clasts of fine-grained basalt, plagioclase and clinopyroxene crystal fragments, and altered glass in a cement of clay + phillipsite. Despite fragmentation, however, there is no evidence of shearing and/or displacement across the brecciated zone. The dike margin in Piece 9 $\mathrm{C}$ of the same core is irregular and highly brecciated with centimeter-size clasts of the host rock and millimeter- to centimeter-size clasts of the chilled margin cemented mainly by clay minerals and minor carbonate. Brecciation is interpreted to be associated with the intrusion and propagation of the dike tip.

The second intrusive contact in Sample 148-896A-22R-4 (Piece 5 ) is a sharp and planar dike margin dipping at $74^{\circ}$. Its possible association with a vein or breccia zone could not be documented as a result of poor recovery of the core piece.

\section{BASEMENT STRUCTURE FROM GEOPHYSICAL MEASUREMENTS}

Mapping of nearly 7700 features on images made with the Formation MicroScanner (FMS, Schlumberger ${ }^{\mathrm{TM}}$ ) has revealed the presence of intensely fractured zones in the basement of Hole 896A (Larouzière et al., this volume). Sharp changes in acoustic velocity and electrical resistivity occur at 325,355 , and $385 \mathrm{mbsf}$ in the hole pointing to the existence of these fractured intervals with thicknesses ranging from 5 to $10 \mathrm{~m}$, as detected both in the dual laterog (DLL) and FMS images. The majority of fractures in these zones is subvertical. The fracture zone at 356 mbsf is of particular importance because it coincides with the lowest electrical resistivity value recorded in Hole 896A and separates fracture sets with two different strike directions (Larouzière et al., this volume). Subvertical to moderately dipping fractures above this zone have a mean azimuth of $145^{\circ} \mathrm{N}$ 
Table 1. Summary of faults observed in cores drilled from Hole 896A.

\begin{tabular}{|c|c|c|c|c|c|c|c|c|c|}
\hline \multirow[b]{2}{*}{$\begin{array}{l}\text { Core, } \\
\text { section }\end{array}$} & \multirow[b]{2}{*}{$\begin{array}{c}\text { Piece } \\
\text { no. }\end{array}$} & \multirow[b]{2}{*}{$\begin{array}{l}\text { Depth } \\
\text { (mbsf) }\end{array}$} & \multicolumn{2}{|c|}{ Dip } & \multicolumn{2}{|c|}{ Fibers } & \multirow[b]{2}{*}{ Composition } & \multirow[b]{2}{*}{ Sense of shear } & \multirow[b]{2}{*}{ Comments } \\
\hline & & & Direction & $\begin{array}{l}\text { Angle } \\
\left.\text { ( }{ }^{\circ}\right)\end{array}$ & Trend & $\begin{array}{l}\text { Plunge } \\
\left({ }^{\circ}\right)\end{array}$ & & & \\
\hline $16 \mathrm{R}-1$ & 9 & 334.7 & 36 & 88 & 306 & 5 & $\mathrm{Fe}-\mathrm{OH} /$ green clay & & Fibers and some polishing \\
\hline $16 \mathrm{R}-1$ & 9 & 334.8 & 238 & 79 & 327 & 4 & $\mathrm{Fe}-\mathrm{OH} /$ green clay & & Fibers and some polishing \\
\hline $16 \mathrm{R}-1$ & 9 & 335.1 & 220 & 87 & 131 & 23 & $\mathrm{Fe}$-OH/green clay & Oblique sinistral & \\
\hline $16 R-3$ & 5 & 337.7 & & 48 & & & $\mathrm{Fe}-\mathrm{OH} /$ green clay & & Polished, no fibers \\
\hline $22 \mathrm{R}-3$ & 2 & 385.6 & 117 & 56 & 117 & 40 & $\mathrm{Fe}-\mathrm{OH} /$ green clay & Normal & Oblique fibers \\
\hline $22 \mathrm{R}-3$ & 2 & 385.6 & 14 & 90 & 32 & 75 & Light-green clay & Normal & \\
\hline $22 \mathrm{R}-3$ & 5 & 385.9 & & 78 & & 19 & Light- + dark-green clay & Oblique sinistral & Fibers overgrowing vermicular clay \\
\hline $22 \mathrm{R}-3$ & 8 & 386.2 & & 41 & & 41 & Light- + dark-green clay & Reverse & \\
\hline $22 \mathrm{R}-3$ & 8 & 386.2 & & 78 & & 78 & Light- + dark-green clay & Reverse & \\
\hline $23 \mathrm{R}-2$ & 16 & 394.3 & 92 & 61 & 58 & 56 & Clay & & Oblique reverse \\
\hline $24 \mathrm{R}-1$ & 9 & 403.1 & & 39 & & & Dark-green clay & Reverse & \\
\hline $24 \mathrm{R}-2$ & 4 & 403.7 & & 72 & & 71 & Light-green clay & Reverse & \\
\hline $24 \mathrm{R}-2$ & 10 & 404.1 & 162 & 72 & & & Dark-green clay & & Cataclastic? \\
\hline $24 \mathrm{R}-2$ & 10 & 404.2 & 99 & 32 & & & Clay & & Cataclastic? \\
\hline $24 \mathrm{R}-2$ & 11 & 404.3 & & 32 & & & Clay & & Cataclastic? \\
\hline \multirow[t]{3}{*}{$24 \mathrm{R}-3$} & 12 & 405.8 & & 79 & & 14 & Dark-green clay & Oblique strike-slip & Three directions of fibers \\
\hline & & & & & & 48 & Dark-green clay & Oblique normal & Same as surface above \\
\hline & & & & & & 49 & Dark-green clay & Oblique reverse & Same as surface above \\
\hline $25 \mathrm{R}-1$ & 11 & 413.7 & & 25 & & & Clay/carbonate & & \\
\hline
\end{tabular}

Note: Sense of shear determined from steps or obliquity of fibers.
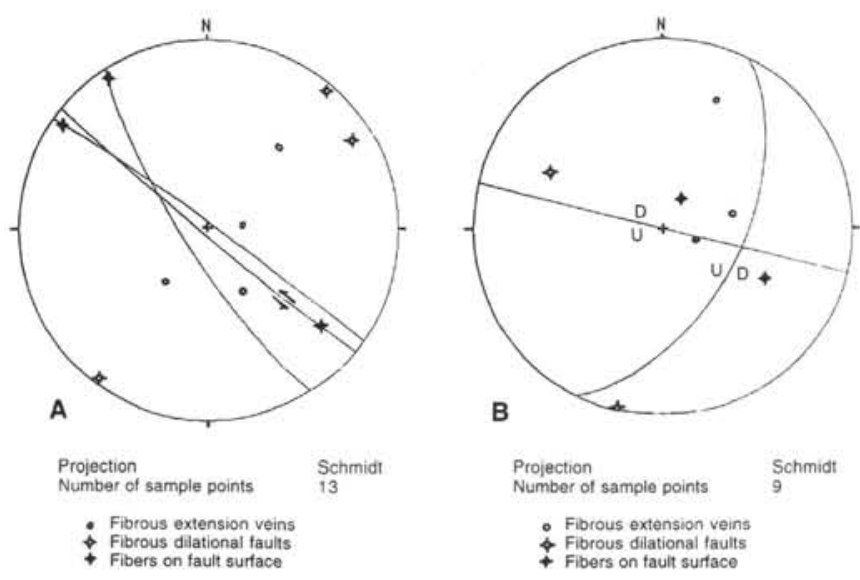

Figure 15. Equal-area stereonets showing poles to vein faults with fibrous slickensides. Veins are extensional with wall-perpendicular fibers. A. Sample 148-896A-16R-1 (Piece 9). B. Sample 148-896A-22R-3 (Piece 2). See text for discussion.

whereas those below $005^{\circ} \mathrm{N}$. In addition, a significant change of the borehole shape from elliptical above this zone to cylindrical below suggests a shift in the modern stress field conditions. On the basis of these observations, Larouzière et al. (this volume) have interpreted this intensely fractured interval at 356 mbsf as an active fault zone.

Measurements of the bulk permeabilities through packer experiments in the basement penetrated by Hole $896 \mathrm{~A}$ have shown that the upper $200 \mathrm{~m}$ of upper oceanic crust is quite permeable with average permeability values typical of the upper oceanic crust off-axis (Becker, this volume). There is no sharp downhole reduction in permeability, suggesting that the basement is consistently permeable enough to support passive off-axis hydrothermal circulation. This permeability structure is compatible with the presence of highly fractured intervals and a fault zone in the basement as inferred from FMS electrical images.

Magnetic properties of the basement in Hole 896A show a variation with depth (Shipboard Scientific Party, 1993) and significant changes at about $330 \mathrm{mbsf}$ and at $360 \mathrm{mbsf}$ (Allerton et al., this volume). Both of these breaks nearly correspond to the tops of massive flow units and separate the basement into three sections that have different magnetic properties. The magnetic susceptibility of the rock samples increases below $330 \mathrm{mbsf}$, and again below $360 \mathrm{mbsf}$, with

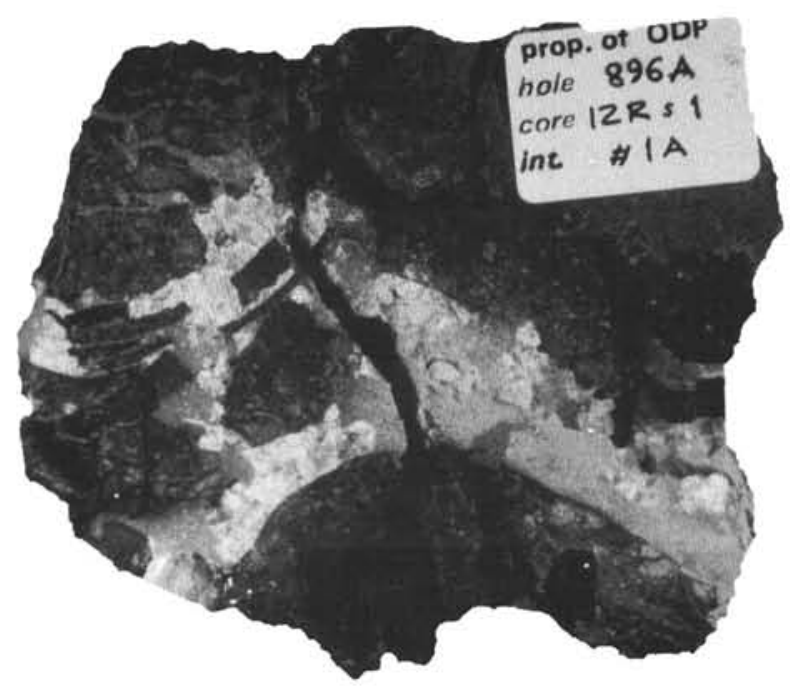

Figure 16. Hyaloclastite breccias near pillow margins. Clasts are mostly altered volcanic glass; matrix consists of vermicular clay and cloudy carbonate minerals. Sample 148-896A-12R-1 (Piece 1A).

an increase in variability, and these changes do not correspond to the petrological changes observed in the core (Allerton et al., this volume). The presence of highly scattered inclinations below $360 \mathrm{mbsf}$ and a clear linear magnetization with subhorizontal inclinations (mean inclination $=-7.5^{\circ} \pm 10.2^{\circ}$ ) above it points to a major break at this zone that nearly coincides with the fault zone at $356 \mathrm{mbsf}$ inferred from the FMS data.

\section{ANALYSIS OF PHYLLOSILICATE MINERALS IN VEINS}

Thin sections of 31 rock samples collected between 195.7 and $460.8 \mathrm{mbsf}$ were studied petrographically to establish phyllosilicate mineralogy and paragenesis in the veins, and to identify those samples in which textural relationships were appropriate for further study. All samples were analyzed initially by powder X-ray diffraction (XRD) for the occurrence of phyllosilicate minerals. Selected samples were analyzed by electron microprobe (EMP) and backscattered electron (BSE) imagery to identify phyllosilicate phases and 

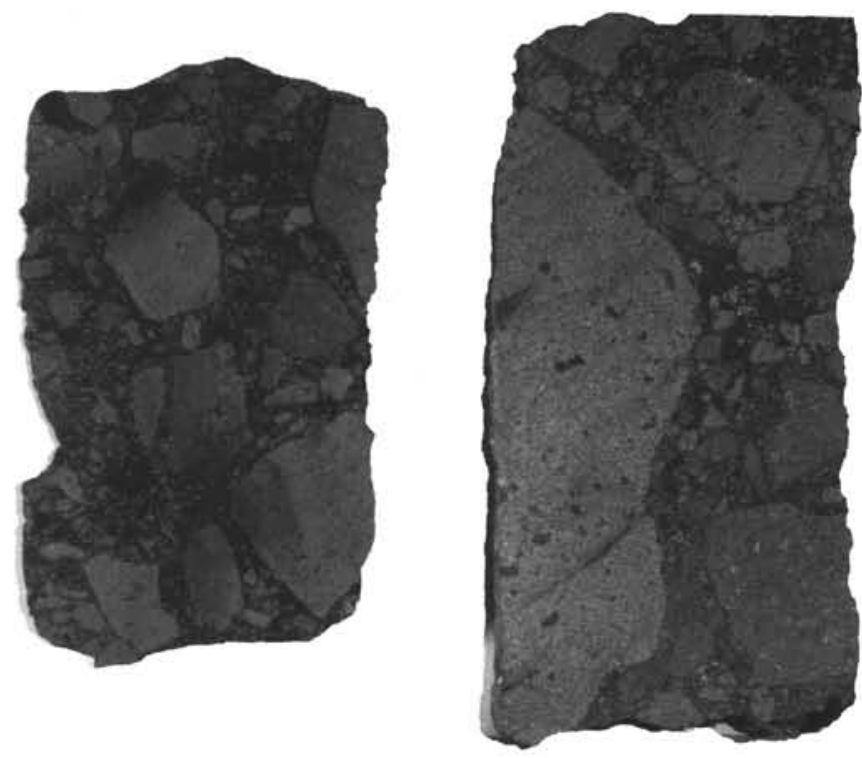

Figure 17. Brecciated basalt with angular to subangular and poorly sorted clasts in a clay cement. Samples 148-896A-27R-2 (Piece 7) on the left and 27R-2 (Piece 5B) on the right.

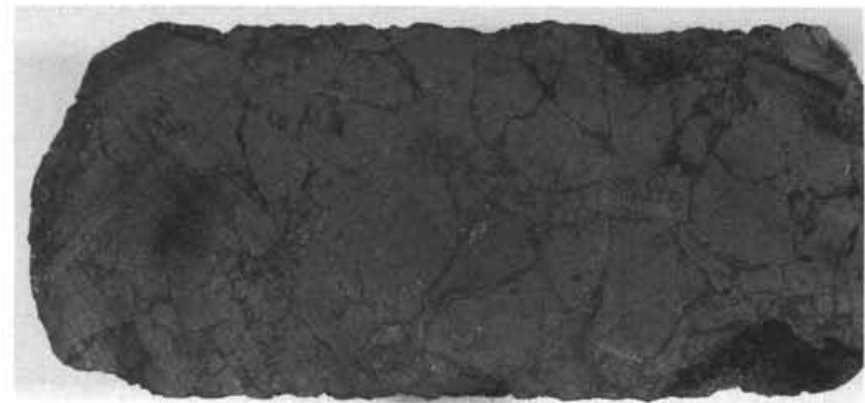

Figure 18. "Jigsaw puzzle" fabric of an incipient breccia in a pillow lava unit (Unit 42). Vein network is composed mainly of clay minerals. Sample 148896A-27R-1 (Piece 3).

quantify their compositions. Computer models of the XRD patterns of these same samples, constrained by EMP analyses, were generated using NEWMOD (Reynolds, 1985). Analytical methods of the phyllosilicate study are discussed in Appendix A.

The XRD analyses of samples in this study, covering the depth range between 195 and $460 \mathrm{mbsf}$, indicate that smectite is present in every sample and is the only clay mineral in all samples excepting those found around $440 \mathrm{mbsf}$, where chlorite/smectite and chlorite are found (Fig. 20). At 440.1 mbsf, chlorite/smectite (nearly 50:50; ordering not determined) coexists with smectite. At 440.9 mbsf, the chlorite/smectite disappears and discrete chlorite coexists with smectite. At 459.6 mbsf smectite is again the dominant phyllosilicate. The results suggest that smectite converts to chlorite through an intermediate chlorite/smectite phase within a very limited interval in response to localized conditions of fluid flow or host rock composition (see Appendix B).

The transformation of smectite to chlorite is abrupt in these samples and is accompanied by the presence of discrete smectite at all times. The transition from smectite to XRD-recognizable chlorite/ smectite occurs in less than $10 \mathrm{~m}$, and the transition from chlorite/ smectite to chlorite occurs in less than $1 \mathrm{~m}$. Figure 21 is a high-resolution XRD scan of the region between $8^{\circ}$ and $14^{\circ} 2 \theta$ showing the presence of discrete smectite in both samples, and the lack of any chlorite/smectite peak in the deeper sample. These data suggest that

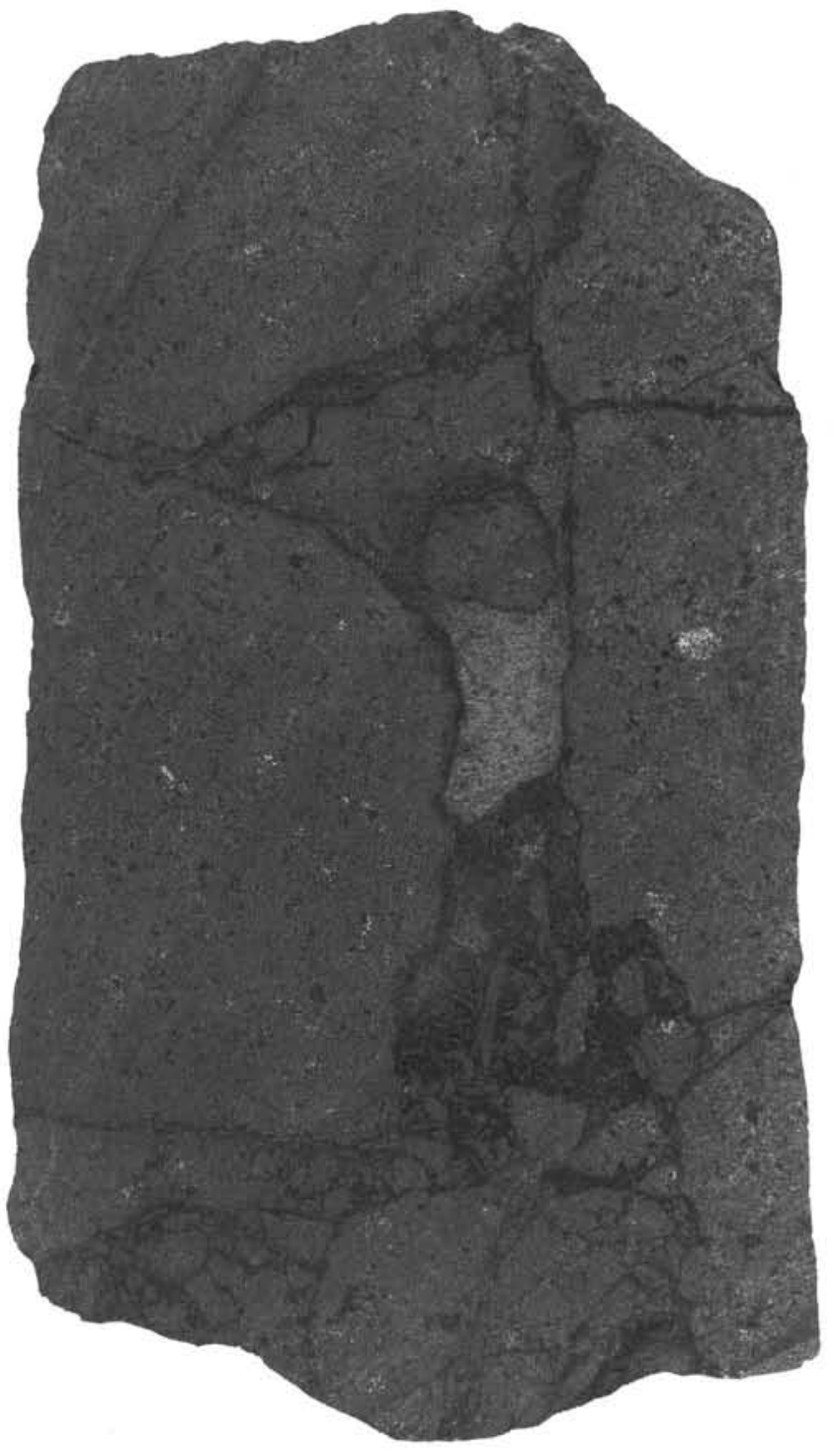

Figure 19. Advanced stage of brecciation in a massive lava unit (Unit 36). Note the matrix made of vermicular clay in the center of the photo. Sample 148-896A-23R-1 (Piece 15).

chlorite/smectite domains in the shallower sample have converted completely to chlorite, whereas other domains have remained pure smectite. Once chlorite forms, no trace of chlorite/smectite remains. According to BSE and EMP results, discrete chlorite and discrete smectite occur in different locations in space of a single thin section.

Several properties of the system may have an influence on the transition from smectite to chlorite. First, temperature may be a controlling factor, although the samples used in this study show that a simple depth/temperature relationship was not solely responsible for the smectite-chlorite transformation in these rocks. It is possible that domains of smectite convert to chlorite throughout a range of temperatures, and that other factors including local temperature variations may control the range of domains and temperatures of conversion until a certain temperature is reached at which all of the smectite is converted. Second, the physical character of the host rock may also be an important control on the smectite to chlorite transition in the samples under study. The XRD-determined mineralogy of these rocks correlates with host-rock type in that smectite occurs exclusively in the upper and lower sections made up of fractured basalt, whereas smectite, chlorite, and mixed chlorite/smectite occur in the middle section composed of pillow lavas and hyaloclastite breccia. The character of 


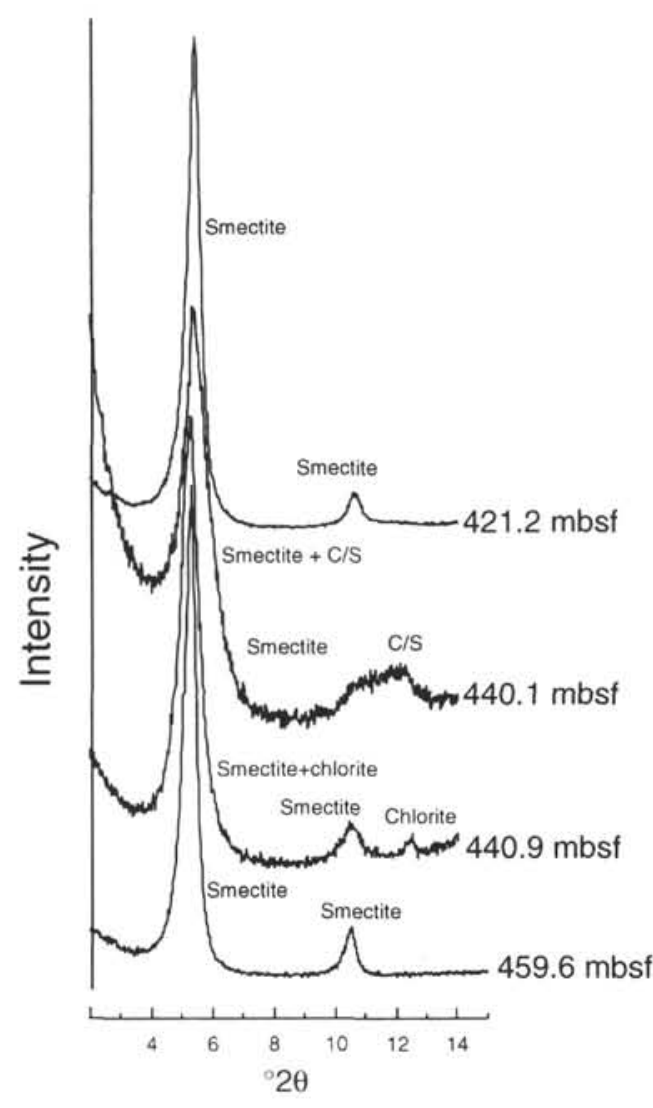

Figure 20. Low-angle region of XRD $(\mathrm{CuK} \alpha)$ patterns showing variations in smectite (Sm), mixed-layered chlorite/smectite (C/S), and chlorite (Chl). Top to bottom the samples are 148-896A-26R-1, 35-40 cm (Piece 6A) $(421.2$ mbsf); 28R-1, 30-34 cm (Piece 5) (440.1 mbsf); 28R-1, 93-96 cm (Piece 18A) (440.9 mbsf); and 30R-1, 40-42 cm (Piece 7) (459.6 mbsf).

the host rock will not only exercise some control over the porosity, but in areas of hyaloclastites devitrification of basaltic glass may provide a ready source of cations for chlorite-forming reactions. Finally, porosity may influence the smectite-chlorite transition because it affects the permeability of the basement that in turn controls the penetration of seawater and hence the degree of alteration. The nearly uniform permeability structure in the basement of Hole 896A (Beck$\mathrm{er}$, this volume) suggests that there are no significant changes in the level of porosity, except where there are highly fractured intervals and fault zones (Larouzière et al., this volume). In our study discrete smectite is found in all samples, and there appears to be no correlation between the occurrences of chlorite and interstratified chlorite/ smectite and the level of porosity.

The transformation of smectite to chlorite through intermediate mixed-layered chlorite/smectite phase or phases has been most likely controlled by a complex interplay among temperature, porosity, physical nature and composition of the host rock, and composition and paths of fluids in the upper ocean crust. The ongoing studies on the evaluation of downhole changes in physical properties and the nature of structures are anticipated to provide essential information to address this problem.

\section{DOWNHOLE VARIATIONS}

Hole 896A contains fifty lithological units consisting mainly of sparsely to highly phyric plagioclase-olivine basalts or olivine-plagioclase basalts with minor occurrences of moderately olivine-phyric

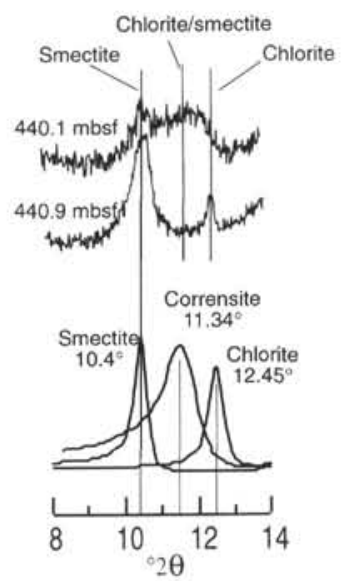

Figure 21. Experimental (top) and calculated (bottom) XRD patterns for region between 8 and $14^{\circ} 2 \theta(\mathrm{CuK} \alpha)$ showing locations of diagnostic peaks from smectite, 50:50 RI chlorite/smectite (corrensite), and chlorite.

basalts (Shipboard Scientific Party, 1993). Whereas the plagioclaseolivine phyric basalts constitute $90 \%$ of the lithological units in the upper volcanic section between 195.1 and $390.1 \mathrm{mbsf}$, olivine-plagioclase phyric lavas make up $72 \%$ of the lower volcanic section between 390.1 and $469 \mathrm{mbsf}$. Both upper and volcanic sections include massive and pillowed flows with locally well-developed breccia zones; however, massive lava flows appear to be more extensive in the upper volcanic section. All these rocks show varying degrees of low temperature $\left(<100^{\circ} \mathrm{C}\right)$ background alteration, with superimposed hydrothermal alteration associated with development of veins and vein systems (Shipboard Scientific Party, 1993). Veins characterize the main mode of brittle deformation in the core.

Fibrous and nonfibrous veins occur throughout the core in most lithological units. Fibrous veins, composed mainly of clay + carbonate and carbonate minerals, occur mostly in Cores 896A-1R-3R, 5R$15 \mathrm{R}, 17 \mathrm{R}, 20 \mathrm{R}-21 \mathrm{R}, 24 \mathrm{R}-26 \mathrm{R}$, and $28 \mathrm{R}$, and the intensity of their occurrence decreases with depth. Fibers are generally wall perpendicular, but the frequency of the occurrence of oblique fibers increases downsection in the core. These veins are consistently late-stage throughout the core, cutting across the other vein types when they intersect. They display moderate to shallow dip angles, which do not show any systematic pattern with depth. Their thickness appears to decrease with depth.

Nonfibrous veins filled mainly with clay minerals show a sharp increase in their occurrence in Cores $15 \mathrm{R}$ to $18 \mathrm{R}$ between 325 and 355 mbsf. Dip angles vary considerably throughout the core. Generally, they are thinner than $1 \mathrm{~mm}$ below 350 mbsf.

There is a significant change in the phyllosilicate structures of the vein-filling minerals at a depth around 440 mbsf in Hole 896A. The transformation of smectite to chlorite occurs at this depth through a mixed-layered transition zone. Smectite becomes predominant again below this depth.

Figure 22 shows the distribution of paleomagnetically corrected true dips of all vein generations with depth in Hole 896A. Dip angles change considerably in the core and do not show any pattern with depth. The complex vein geometry and orientation in recovered core samples imply that extension occurred in virtually all directions in upper Layer 2 in Hole 896A.

The breccias occur sporadically in the core but more extensively in the upper volcanic section (Shipboard Scientific Party, 1993). Major breccia horizons were recovered in Unit 10 in Section 896A-5R1 (228.9 mbsf), Unit 13 in Section 7R-1 (247.9 mbsf), Unit 14 in Section 8R-1 (257.45 mbsf), Unit 14 in Section 9R-1 (267.3 mbsf), Unit 14 in Section 11R-2 (287.74-288 mbsf), Unit 19 in Section 14R-1 (315.25 mbsf), Unit 30 in Section 18R-2 (354.75 mbsf), Unit 30 in 


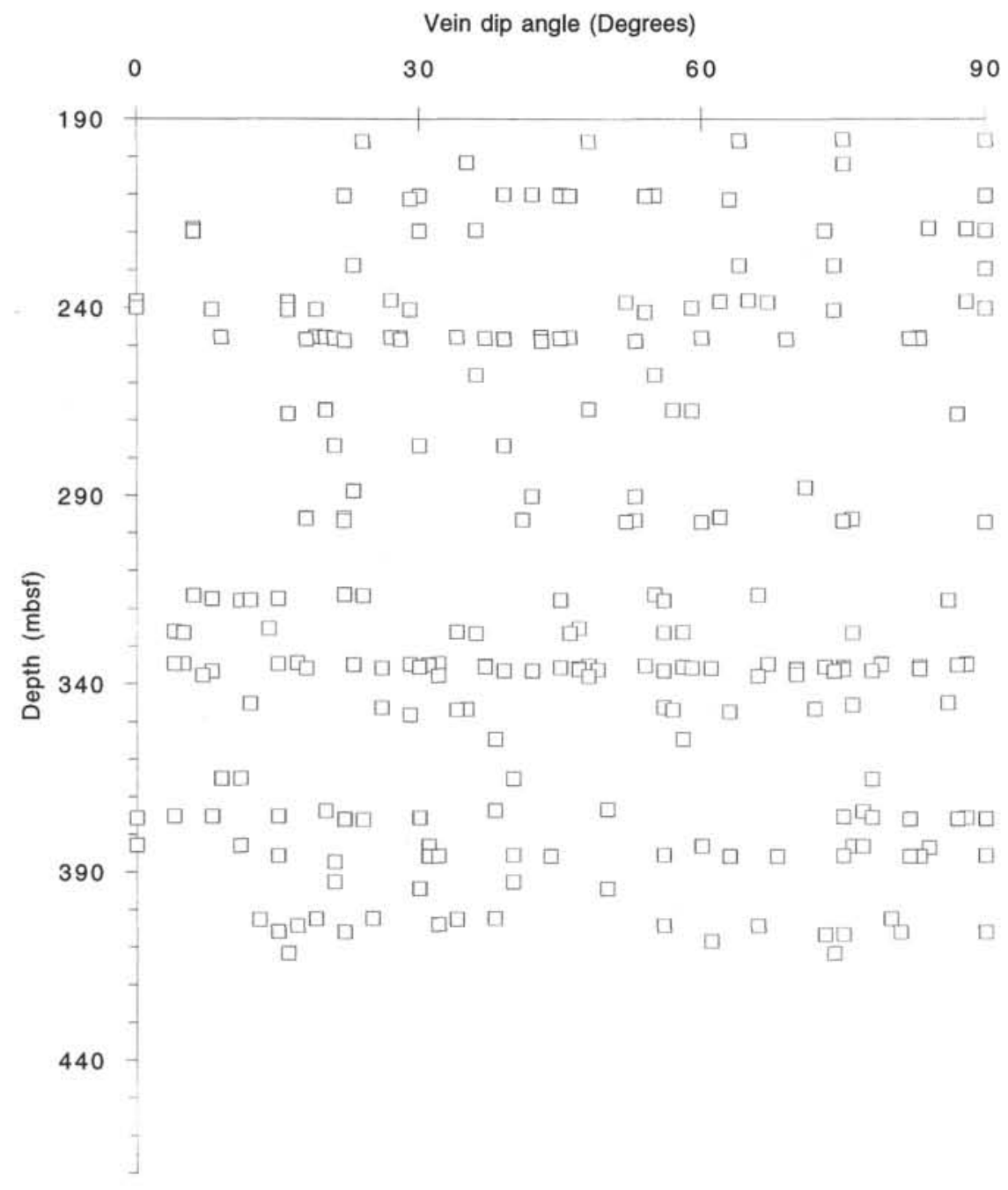

Figure 22. Distribution of dip angles of all vein generations with depth in Hole 896A. See text for discussion.
Section 18R-2 (354.75 mbsf), Unit 30 in Section 20R-1 (363.5 mbsf), Unit 35 in Section 23R-1 (392.1 mbsf), Unit 44 in Section 27R-1 (431.60 mbsf), Unit 44 in Section 27R-2 (432.0-432.95 mbsf), and Unit 50 in Section 30R-1 (459.5-460.2 mbsf). All these breccia occurrences, with the exception of that in Unit 35 in Core 23R-1, are spatially associated with pillow lavas; the breccias in Section 23R-1 overlie a massive lava unit composed of moderately phyric plagioclase-olivine basalt. The apparent downhole decrease in the presence of breccias is consistent with the interpretation that brecciation occurred in the uppermost crust as a result of subseafloor fragmentation and disaggregation of cooling lavas under low confining pressures. As the confining pressure increases with depth, such fragmentation decreases. However, high pore-fluid pressure can take over at these depths, causing brecciation and development of complex network of vein systems.

\section{COMPARISON WITH HOLE 504B}

The volcanic sequence penetrated by Hole 504B contains 1287.8 $\mathrm{m}$ of oceanic basalts and includes three major lithostratigraphic zones (Anderson et al., 1982; Adamson, 1985; Anderson, Honnerez, Becker, et al., 1985; Becker et al., 1989). These zones are (1) $571.5 \mathrm{~m}$ mainly of pillow lavas and thin flows, intercalated with pillow breccias, hyaloclastites, massive basalts, and localized flow and tectonic breccias (274.5-846 mbsf); (2) a 209-m-thick transition zone com- posed of pillow lavas, thin flows, massive basalts, and dikes (846$1055 \mathrm{mbsf}$ ); and (3) $507.3 \mathrm{~m}$ of sheeted dikes and massive basalts (1055-1562.3 mbsf). The rocks are predominantly fine- to mediumgrained, aphyric to highly phyric, tholeiitic basalts that are altered to some degree (Becker et al., 1989). Alteration in Hole 504B basalts shows three zones with distinct assemblages of secondary minerals (Honnorez et al., 1985; Alt et al., 1986): (1) the upper pillow alteration zone ( $320 \mathrm{~m}$ of the pillow lavas) characterized by oxidative alteration; (2) the deeper extrusive section $(320-624 \mathrm{~m})$ and the topmost $52 \mathrm{~m}$ of the lithologic transition zone, characterized by smectite and pyrite; and (3) the combined transition zone and dike section $(624-1075.5 \mathrm{~m})$ characterized by greenschist-facies minerals.

The type and occurrence of major alteration minerals associated with bulk rock and vein hydrothermal alteration observed in Hole $896 \mathrm{~A}$ are similar to those documented in the upper pillow alteration zone in the 504B core (Shipboard Scientific Party, 1993; Laverne et al., this volume). Thus, the cored sub-basement (total of $290 \mathrm{~m}$ ) in Hole $896 \mathrm{~A}$ is analogous to the upper part $(320 \mathrm{~m})$ of the extrusive sequence in Hole 504B in terms of alteration characteristics. However, the mode and nature of hydrothermal veins observed in these holes show some differences. In general, there exists a greater number of veins crosscutting both pillow and massive lava units in Hole 896A compared to Hole 504B, and the veins are commonly thicker particularly in the uppermost part of the volcanic sequence in Hole 896A. The late-stage fibrous veins filled with carbonate minerals (particularly aragonite) also seem to be more abundant in the Hole $896 \mathrm{~A}$ 
core. Information on the orientation of veins and vein generations is not available from the Hole 504B core, and thus a comparison regarding the vein attitudes is not possible.

There are two major differences in the lithostratigraphy of Holes 504B and 896A (Shipboard Scientific Party, 1993). Massive lava units intercalated with pillow lavas are more abundant in the cores from Hole 896A. They may represent single or multiple eruptions of magma (Allerton et al., this volume). Such massive and sheet lava flows are widespread within the rift valleys of intermediate- and fastspreading ridges and are interpreted to represent brief but voluminous eruptions (Ballard et al., 1979). Breccias and hyaloclastites occur also more commonly in the cores of Hole 896A. They are particularly abundant in the upper part (top $370 \mathrm{~m}$ ) of the core and are commonly spatially associated with glassy rinds of pillow lavas. Extreme enrichments of $\mathrm{Mg}$, alkalies, and $\mathrm{CO}_{2}$ in these breccia zones indicate that development and the existence of breccias facilitated and supported intense geochemical changes in the basement (Teagle et al., this volume).

The presence of abundant veins and breccias in the core suggests that the basaltic basement in Hole 896A was affected by interaction with seawater and high pore fluid pressures. The uniform permeability structure in the basement of Hole 896A has similar upper crustal permeability values as in Hole 504B and other upper crustal holes in various tectonic settings (Becker, this volume). Extended and fractured upper oceanic crust in Hole 896A appears to have been locally sealed with clay and carbonate minerals causing increased fluid pressures in the groundwater. This phenomenon is probably related to the presence of higher heat flow values and upwelling basement groundwaters at the site overlying a basement topographic high on the inferred footwall of a fault dipping north towards Hole 504B.

\section{SUMMARY}

Major volcanic units recovered in 30 cores from Hole 896A include predominantly pillow basalts and minor massive lava flows and breccias. The principal structures encountered in these volcanic units are veins and vein systems, vein faults and fractures, breccias, and rare intrusive contacts. Veins are categorized in two groups on the basis of their internal structure and fabric and mineral composition of vein-filling minerals. Structurally categorized veins include fibrous and nonfibrous ones. Fibrous veins, composed mainly of carbonate + clay and carbonate minerals, are commonly younger than other vein types on the basis of crosscutting relationships, and they display shallow to moderate dip angles. Wall-perpendicular fibers in most of these veins imply pure extension that was accompanied by a succession of crack-seal increments. Nonfibrous veins are generally filled with blocky carbonate/clay minerals, and/or Fe-oxyhydroxide, and in general they represent early stages of veining in the upper ocean crust. Whereas some are spatially associated with chilled margins and rims of pillows suggesting their formation during cooling of pillow lava flows, others (e.g., Fe-oxyhydroxide + clay and dark-green clay) are more common in massive lavas. These vein types, which display moderate to steep dip angles, may represent steeply dipping cooling joints in massive lava flows. Some nonfibrous, clay + carbonate veins at $441 \mathrm{mbsf}$ show extension in many directions within a nearly north-south-striking subvertical plane.

The sense of shearing along several vein faults in the core from depths of 335 to 406 mbsf points to a compressional origin rather than extensional. Many clay veins are fractured as a result of the decompression of clay minerals after drilling.

Breccias, comprising $5 \%$ of the drilled section, occur mainly in the upper part of the core and include hyaloclastites, angular basalt breccias, and breccias with a "jigsaw puzzle" fabric. The main mechanisms of brecciation are thought to be fragmentation of glassy pillow rims, mass wasting on the seafloor, and hydraulic fracturing beneath the seafloor.

\section{ACKNOWLEDGMENTS}

This work was supported by a grant from JOI-USSAC to Y.D. The authors thank the shipboard scientists on Leg 148 for helpful discussions while on board. Constructive and thorough reviews by Paul T. Robinson and Jeff C. Alt improved the paper.

\section{REFERENCES}

Adamson, A.C., 1985. Basement lithostratigraphy, Deep Sea Drilling Project Hole 504B. In Anderson, R.N., Honnorez, J., Becker, K., et al., Init. Repts. DSDP, 83: Washington (U.S. Govt. Printing Office), 121-127.

Alt, J.C., Honnorez, J., Laverne, C., and Emmermann, R., 1986. Hydrothermal alteration of a $1 \mathrm{~km}$ section through the upper oceanic crust, Deep Sea Drilling Project Hole 504B: mineralogy, chemistry, and evolution of seawater-basalt interactions. J. Geophys. Res., 91:10309-10335.

Anderson, R.N., Honnorez, J., Becker, K., Adamson, A.C., Alt, J.C., Emmermann, R., Kempton, P.D., Kinoshita, H., Laverne, C., Mottl, M.J., and Newmark, R.L., 1982. DSDP Hole 504B, the first reference section over $1 \mathrm{~km}$ through Layer 2 of the oceanic crust. Nature, 300:589-594.

Anderson, R.N., Honnorez, J., Becker, K., et al., 1985. Init. Repts. DSDP, 83: Washington (U.S. Govt. Printing Office).

Ballard, R.D., Holcomb, R.T., and van Andel, T.H., 1979. The Galapagos Rift at $86^{\circ} \mathrm{W}: 3$. Sheet flows, collapse pits, and lava lakes of the rift valley. J. Geophys. Res., 84:5407-5422.

Becker, K., Adamson, A.C., Alexandrovich, J., Alt, J.C., Anderson, R.N., et al., 1989. Drilling deep into young oceanic crust, Hole 504B, Costa Rica Rift. Rev. Geophys., 27:79-101.

Cox, S.F., and Etheridge, M.A., 1983. Crack-seal fibre growth mechanisms and their significance in the development of oriented layer silicate microstructures. Tectonophysics, 92:147-170.

Hobart, M.A., Langseth, M.G., and Anderson, R.N., 1985. A geothermal and geophysical survey on the south flank of the Costa Rica Rift: Sites 504 and 505. In Anderson, R.N., Honnorez, J., Becker, K., et al., Init. Repts. DSDP, 83: Washington (U.S. Govt. Printing Office), 379-404.

Honnorez, J., Alt, J.C., Honnorez-Guerstein, B.-M., Laverne, C., Muehlenbachs, K., Ruiz, J., and Saltzman, E., 1985. Stockwork-like sulfide mineralization in young oceanic crust: Deep Sea Drilling Project Hole 504B. In Anderson, R.N., Honnorez, J., Becker, K., et al., Init. Repts. DSDP, 83: Washington (U.S. Govt. Printing Office), 263-282.

Inoue, A., 1985. Conversion of smectite to chlorite by hydrothermal and diagenetic alterations, Hokuroku Kuroko mineralization area, northeast Japan. Proc. Int. Clay Conf., 158-164.

Morin, R.H., Newmark, R.L., Barton, C.A., and Anderson, R.N., 1990. State of lithospheric stress and borehole stability at Deep Sea Drilling Project Site 504B, eastern Equatorial Pacific. J. Geophys. Res., 95:9293-9303.

Pollard, D.D., and Aydin, A., 1988. Progress in understanding jointing over the past century. Geol. Soc. Am. Bull., 100:1181-1204.

Ramsay, J.G., and Huber, M., 1983. The Techniques of Modern Structural Geology (Vol. 1): Strain Analysis: London (Academic Press).

Reynolds, R.C., 1985. NEWMOD-a computer program for the calculations of one-dimensional diffraction profiles of clays: Hanover, $\mathrm{NH}$ (publ. by author).

Shipboard Scientific Party, 1993. Site 896. In Alt, J.C., Kinoshita, H., Stokking, L.B., et al., Proc. ODP, Init. Repts., 148: College Station, TX (Ocean Drilling Program), 123-192.

\footnotetext{
Date of initial receipt: 17 August 1994

Date of acceptance: 22 February 1995

Ms 148SR-133
} 


\section{APPENDIX A}

\section{Analytical Methods for Phyllosilicate Study}

Fifteen rock samples were chosen for X-ray diffraction (XRD) analysis In preparation for XRD study, vein minerals in the thin section billets were plucked out using a dissecting needle and a binocular microscope. The powdered minerals were mounted on a clean petrographic slide with a $1-\mathrm{cm}^{2}$ piece of Scotch ${ }^{\mathrm{TM}}$ double-stick tape. Following a reconnaissance XRD study, seven samples representative of the range of variation encountered were chosen for detailed XRD work and electron microprobe (EMP) analysis. Results from four of these samples are presented in this paper because they represent the range of mineralogical and stratigraphic variation found in the sample suite.

The XRD analyses were performed on a Siemens D-5000 diffractometer using $\mathrm{CuK} \alpha$ radiation $(40 \mathrm{kV}, 30 \mathrm{~mA})$ and a curved-crystal graphite monochromator. Horizontal divergence of the X-ray beam was controlled using a variety of antiscatter slit configurations $\left(1.0^{\circ}, 0.5^{\circ}\right.$, and $0.1^{\circ}$ divergence $)$ depending on the angular range of the analysis. Measurements were made on air-dried samples and after exposure to ethelyne glycol at $60^{\circ} \mathrm{C}$ for a minimum of $8 \mathrm{hr}$, using count times from 2 to $120 \mathrm{~s}$ per $0.02^{\circ} 2 \theta$ step. Initial analytical runs on all 15 samples, plus the mounting medium and the tape blank, were made from $2^{\circ}$ to $35^{\circ} 2 \theta$ ( 2 -s count time/step) to characterize the clay mineral and accessory mineral assemblages. Seven samples, representing the depth range between approximately 420 to $460 \mathrm{mbsf}$, were chosen for further XRD analyses with fine antiscatter slits and long count times of the region below $20^{\circ} 2 \theta$ where the most diagnostic diffraction peaks occur, and for modeling of diffraction patterns as described in the next paragraph. The double-stick tape background was subtracted from each pattern to produce a representative mineral XRD profile.

Calculated patterns of pure, trioctahedral chlorite, pure trioctahedral smectite with 2 glycol layers, and 50:50 chlorite/smectite (corrensite) were produced using NEWMOD2.4.M2* (Reynolds, 1985). These patterns were mixed as appropriate to produce calculated patterns to be compared with experimental XRD data. Iron content for each standard profile was determined on the basis of electron microprobe (EMP) analysis of the sample which most closely resembles the modeled standard. The mean defect-free distance $(\delta)$ was varied between 4 and 5 to model peak breadths, indicating that the coherent X-ray diffracting domains in these clay minerals are quite small along [001].

Evidence for the occurrence of minerals in the smectite-chlorite/smectitechlorite series is best found in the X-ray diffraction profiles in the region between $8^{\circ}$ and $14^{\circ} 2 \theta$ : the smectite 002 peak occurs at about $10.4^{\circ} 2 \theta(8.5 \AA)$ a strong chlorite/smectite peak occurs, depending on the ratio of chlorite and smectite layers, at about $11.5^{\circ} 2 \theta(7.8 \AA)$; and the chlorite 002 peak occurs at about $12.4^{\circ} 2 \theta(7 \AA)$. Additional evidence can be found in the character of the strong peak which occurs in every pattern between 5 and $6^{\circ} 2 \theta$ : a peak at about $5^{\circ} 2 \theta$ with no asymmetry suggests pure smectite, whereas asymmetry on the high angle side of the peak suggests the presence of chlorite/smectite which has a strong peak at around $5.6^{\circ} 2 \theta$.

Electron microprobe analyses were performed on a JEOL JXA-8900 Series Microanalyzer Superprobe, using a combination of wavelength dispersive $\mathrm{X}$-ray spectrometers (WDS) and an energy dispersive X-ray spectrometer (EDS). Samples were analyzed for eight elements as oxides, using the following standards: $\mathrm{Na}$, albite; $\mathrm{Mg}$, periclase; $\mathrm{K}$ and $\mathrm{Al}$, orthoclase; $\mathrm{Si}$, quartz; $\mathrm{Ca}$, diopside; Mn, spessartine garnet; and Fe, hematite. The spot size used was 1 $\mu \mathrm{m}$.

Backscattered electron (BSE) images of the samples were used to select 50 points for analysis. The results represent the average of three to six analyses of material with similar textures and backscattered electron image (BSE) character. Total cation calculations are determined on the basis of 22 oxygen equivalents for smectite ( 14 cations), 25 for corrensite ( 17 cations), and 28 for chlorite ( 20 cations).

\section{APPENDIX B}

\section{Results of the Phyllosilicate Study}

The XRD analyses of all samples in this study, covering the depth range between 195 and $460 \mathrm{mbsf}$, indicate that smectite is present in every sample, and is the only clay mineral in all samples excepting those found around 440 $\mathrm{mbsf}$, where chlorite/smectite and chlorite are found (Fig. 20). Detailed work. therefore, concentrated on the portion of the drill core between 420 and 460 mbsf to bracket the occurrences of chlorite/smectite and chlorite. The selected lithostratigraphic sequence of drill core consists of massive and pillow basalt between 400 and 431.1 mbsf in the upper section, volcanic breccia and pillowlava basalt between 431.1 and $440.9 \mathrm{mbsf}$ in the middle section, and fractured pillow-lava basalt and breccias between 440.9 and $460.8 \mathrm{mbsf}$ in the lower section. A correlation exists between the rock type and the minerals identified by XRD: samples in the upper and lower sections are pure smectite, whereas those in the middle section have mixed-layered chlorite/smectite and pure chlorite as well as smectite.

The following summary of the sample characteristics is given in order of increasing depth. It focuses on four selected samples which show the range of variation in chlorite and smectite in Hole 896A, as well as the stratigraphic relationships of different mineral types.

\section{Sample 148-896A-26R-1, 35-40 cm, Piece 6A (421.2 mbsf)}

Petrographic study of this moderately phyric plagioclase-olivine basalt sample suggests moderate-to-low porosity and a distinction in crystal habit between occurrences of clay minerals. The XRD analyses and modeling of vein minerals in this sample indicate that the clay is pure smectite (Appendix B, Fig. B-1) with coherent diffracting domains averaging 4 unit cells in thickness. Electron microprobe analyses (Appendix B, Table B-1) were made of the two different crystal habits (acicular and radiating bunches) to determine if there is a correlation between chemical composition and crystal habit. Both the radiating bunches and the acicular crystals are $\mathrm{Mg}$-rich and contain primarily smectite ( 14.74 and 14.44 cations per 22 oxygens, respectively). The cation excesses may represent small numbers of chlorite layers interstratified with smectite at a level indiscernible by XRD, or submicroscopic grains of accessory minerals present at the location of the analysis.

\section{Sample 148-896A-28R-1, 30-34 cm, Piece 5 (440.1 mbsf)}

This sample is identified as an intra-pillow breccia. Petrographic study suggests moderate porosity and the presence of radiating bunches of clay minerals, some rimmed by analcime, all of which appear to have varying proportions of chlorite and smectite. The smectite 001 peak visible in the XRD profile (Appendix B, Fig. B-2) exhibits asymmetry on the high-angle side, suggesting the presence of chlorite/smectite. The broad peak at around $11^{\circ} 2 \theta$ is actually composed of two separate peaks, one from smectite (around $10.6^{\circ}$ $2 \theta$ ) and one from chlorite/smectite with a ratio of nearly 50:50 (around $11.5^{\circ}$ 20) (Appendix B, Fig. B-2). Analcime $(211,332$, and 400 peaks) is also present in the XRD analysis. Modeling of the XRD data confirms that both the asymmetry of the peak at around $6^{\circ} 2 \theta$, and the width of the peak at around $11^{\circ} 2 \theta$, could be generated by a physical mixture of smectite and a chlorite/ smectite that is nearly a 50:50 interstratification. EMP analyses were made in three areas which were distinct in BSE images. Two areas (a representative BSE image is shown in Appendix B, Fig. B-3, area A) have cation totals ranging from 16.75 to 16.87 cations per 25 oxygens, suggestive of chlorite/smectite ( 17 cations per 25 oxygens) with a small amount of discrete smectite or accessories in a physical mixture. The third area (Appendix B, Fig. B-3, area

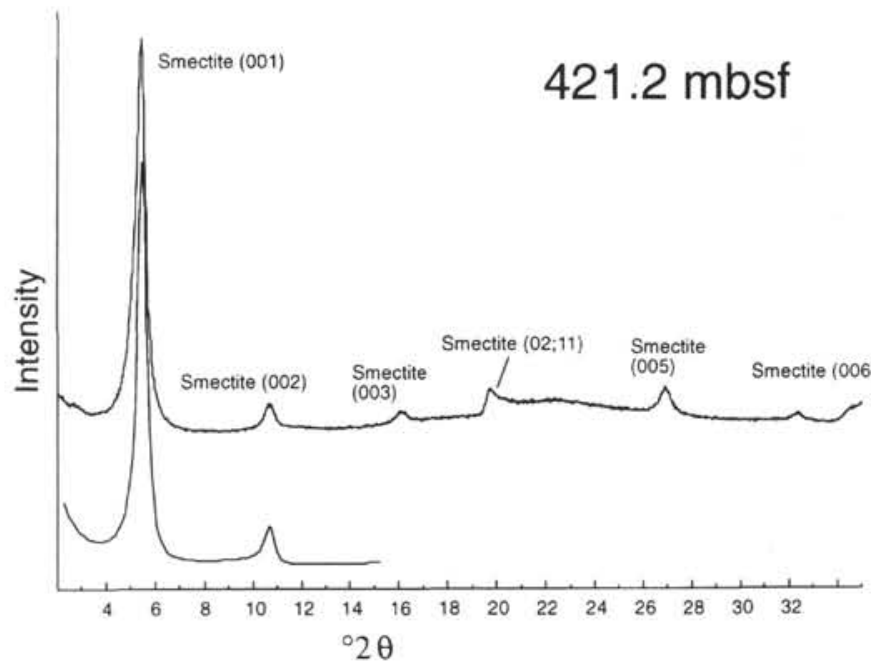

Appendix Figure B-1. XRD (CuK $\alpha$ ) pattern (top) and NEWMOD calculated diffraction pattern (bottom) for Sample 148-896A-26R-1, 35-40 cm (Piece 6A) (421.2 mbsf). 
APPENDIX TABLE B-1

Electron Microprobe Analyses of Phyllosilicates in Selected Samples from Hole 896A

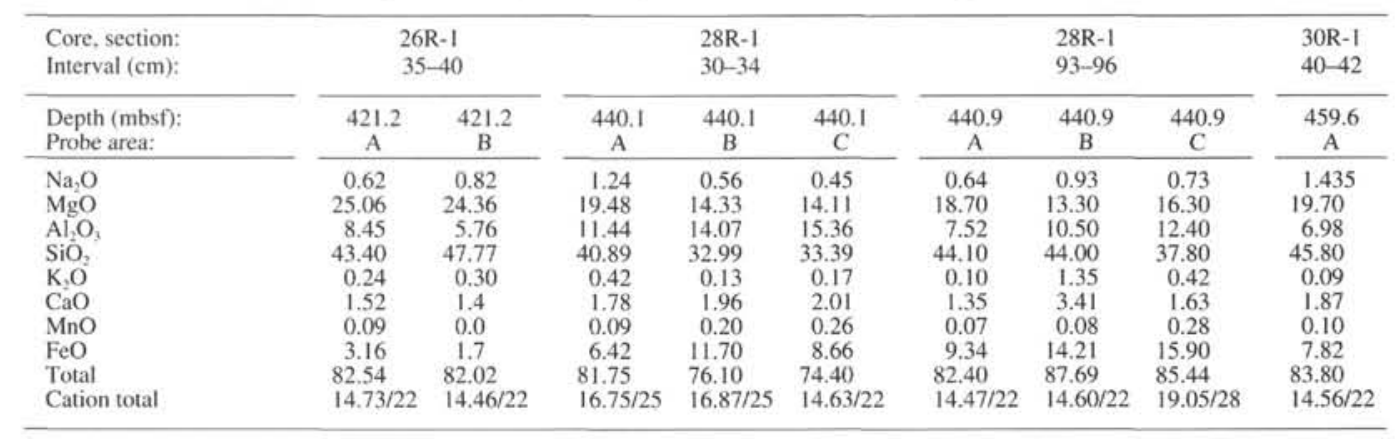

Notes: Total Fe as FeO. Cation totals are recalculated to 22 oxygen for smectite, 25 oxygens for corrensite, and 28 oxygens for chlorite.

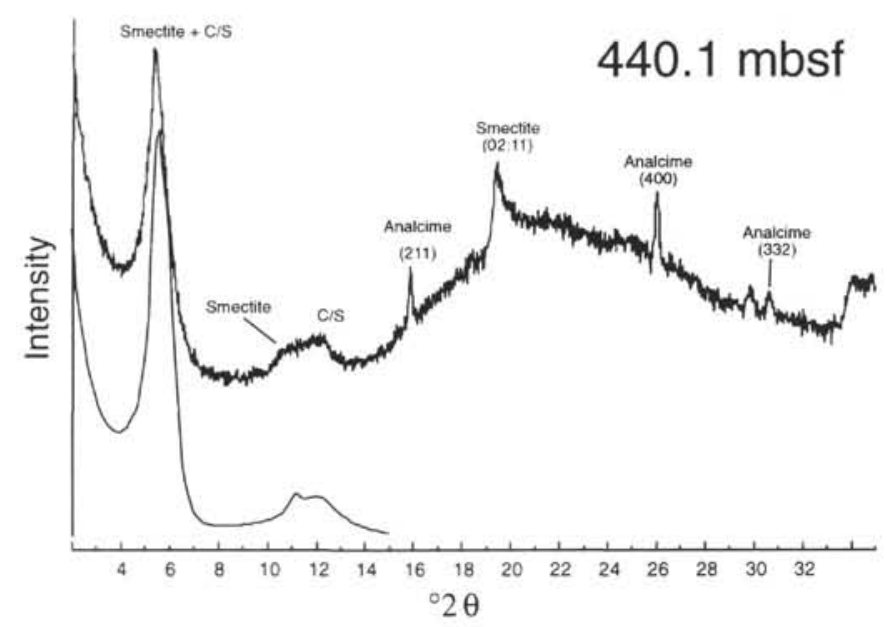

Appendix Figure B-2. XRD (CuK $\alpha$ ) pattern (top) and NEWMOD calculated diffraction pattern (bottom) for Sample 148-896A-28R-1, 30-34 cm (Piece 5) (440.1 mbsf).

B) is smectite rich (14.43 cations per 22 oxygens). Sodium and aluminum are elevated in all analyses, most likely due to the presence of finely divided analcime as a secondary mineral.

\section{Sample 148-896A-28R-1, 93-96 cm, Piece 18A (440.9 mbsf)}

This sample is a breccia with clasts of basalt and hyaloclastic material in a matrix of altered glass. Petrographic study indicates low porosity and the presence of discrete chlorite, discrete smectite, and analcime. The XRD profile for this sample (Appendix B, Fig. B-4) indicates the presence of discrete smectite and chlorite. The diagnostic peak of 50:50 chlorite:smectite between the pure smectite and pure chlorite 002 peaks seen in the previous sample, is not present. The smectite 002 peak is slightly displaced to the right, suggesting the presence of mixed chlorite/smectite. However, this shift may also be due to the large amount of background interference in the profile. Modeling of the XRD data confirms the predominance of discrete smectite and chlorite in this sample. Three areas of clay minerals within this sample were analyzed by EMP (Table B1). Two dark-colored areas of the BSE images (one is shown in Appendix B, Fig. B-5A), are made predominantly of smectite (the cation totals are 14.47 to 14.60 per 22 oxygens). These analyses are also low in aluminum and high in silica, consistent with the composition of smectite. The third area analyzed, from a light-colored area on the BSE image (Appendix B, Fig. B-5B), has a cation total of 19.05 per 28 oxygens, is high in iron and aluminum, and relatively low in silica, corresponding most closely to chlorite.

\section{Sample 148-896A-30R-1, 40-42 cm, Piece 7 (459.6 mbsf)}

This sample is stratigraphically the lowest unit used in this study and is classified as a breccia. Petrographic study indicates high porosity and the occurrence of discrete smectite in radiating bunches of crystals. The XRD pattern for this sample (Appendix B, Fig. B-6) contains a complete series of smectite basal peaks, along with albite and calcite. Modeling confirms that the clays in the sample are nearly pure smectite. Because of the homogeneity of the sample in BSE images, only one area was analyzed by EMP (Table B1). The cation total was closest to that of pure smectite (14.56 cations per 22 oxygens). The sample is high in sodium, most likely because of the occurrence of albite, and low in aluminum, consistent with the smectite-rich interpretation of this material. 


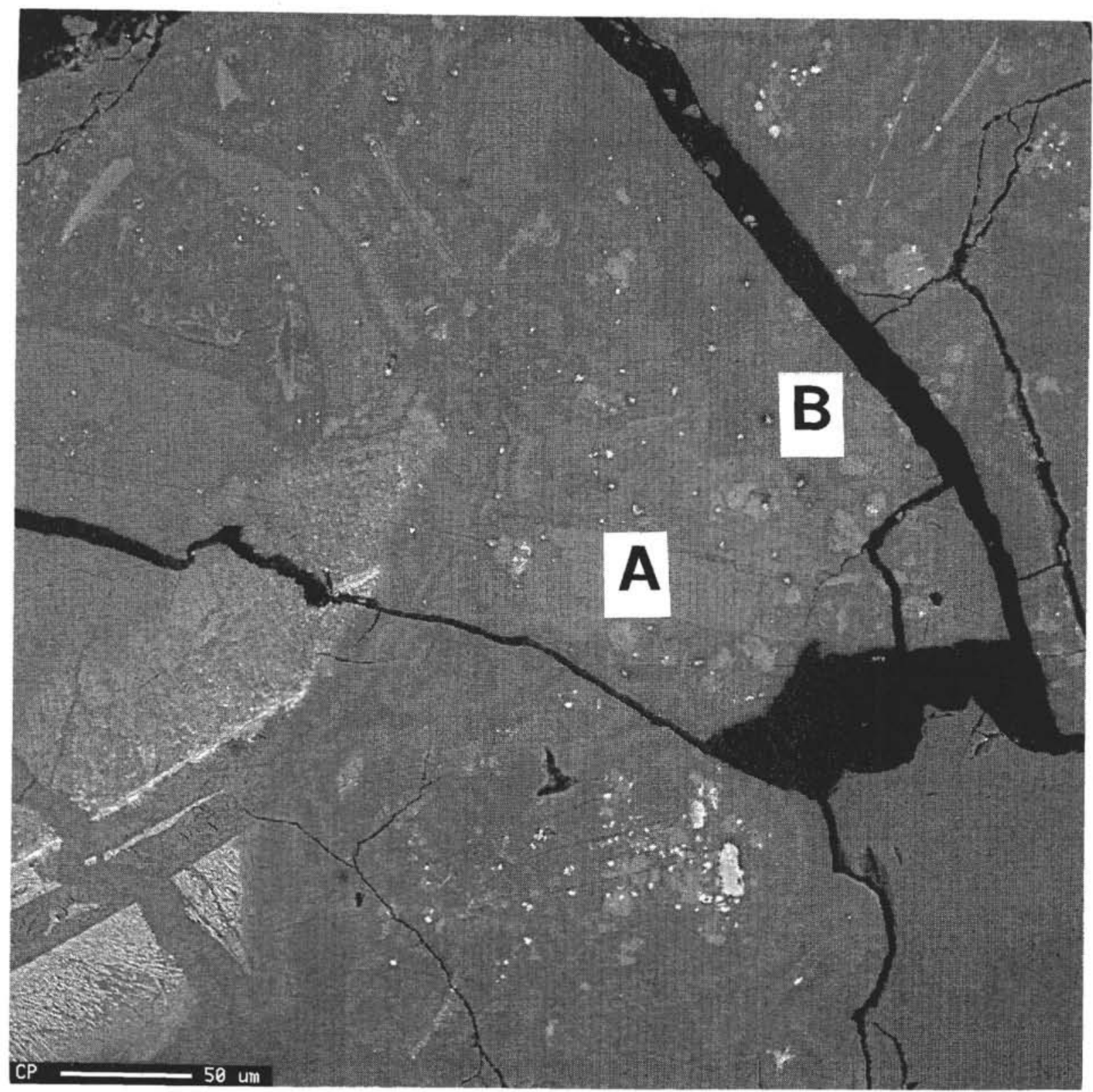

Appendix Figure B-3. Backscattered electron (BSE) image of selected portion of Sample 148-896A-28R-1, 30-34 cm (Piece 5) (440.1 mbsf) showing areas of EMP analyses. 
Y. DILEK ET AL.

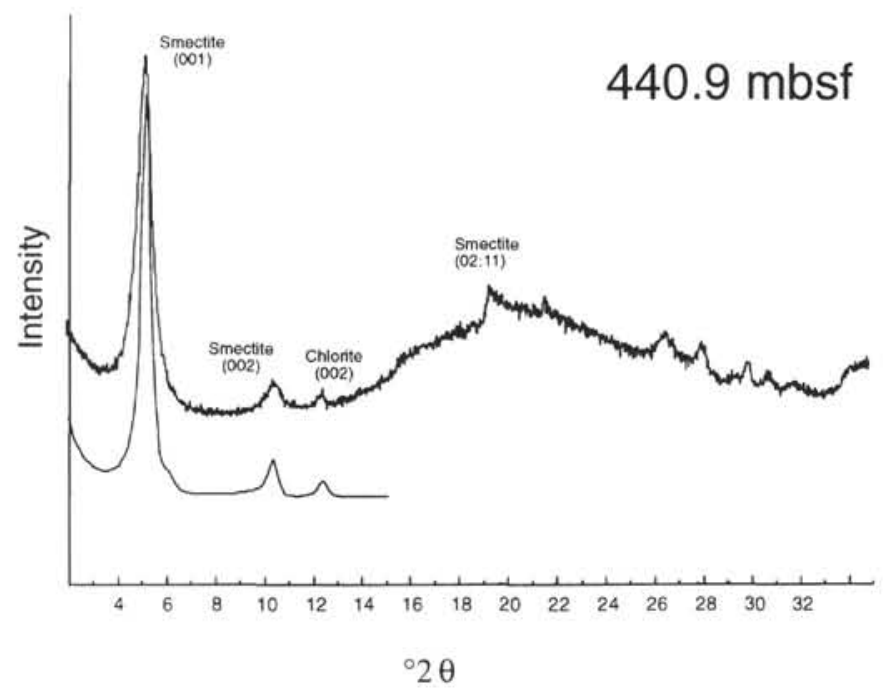

Appendix Figure B-4. XRD (CuK $\alpha$ ) pattern (top) and NEWMOD calculated diffraction pattern (bottom) for Sample 148-896A-28R-1, 93-96 cm (Piece 18A) (440.9 mbsf), 


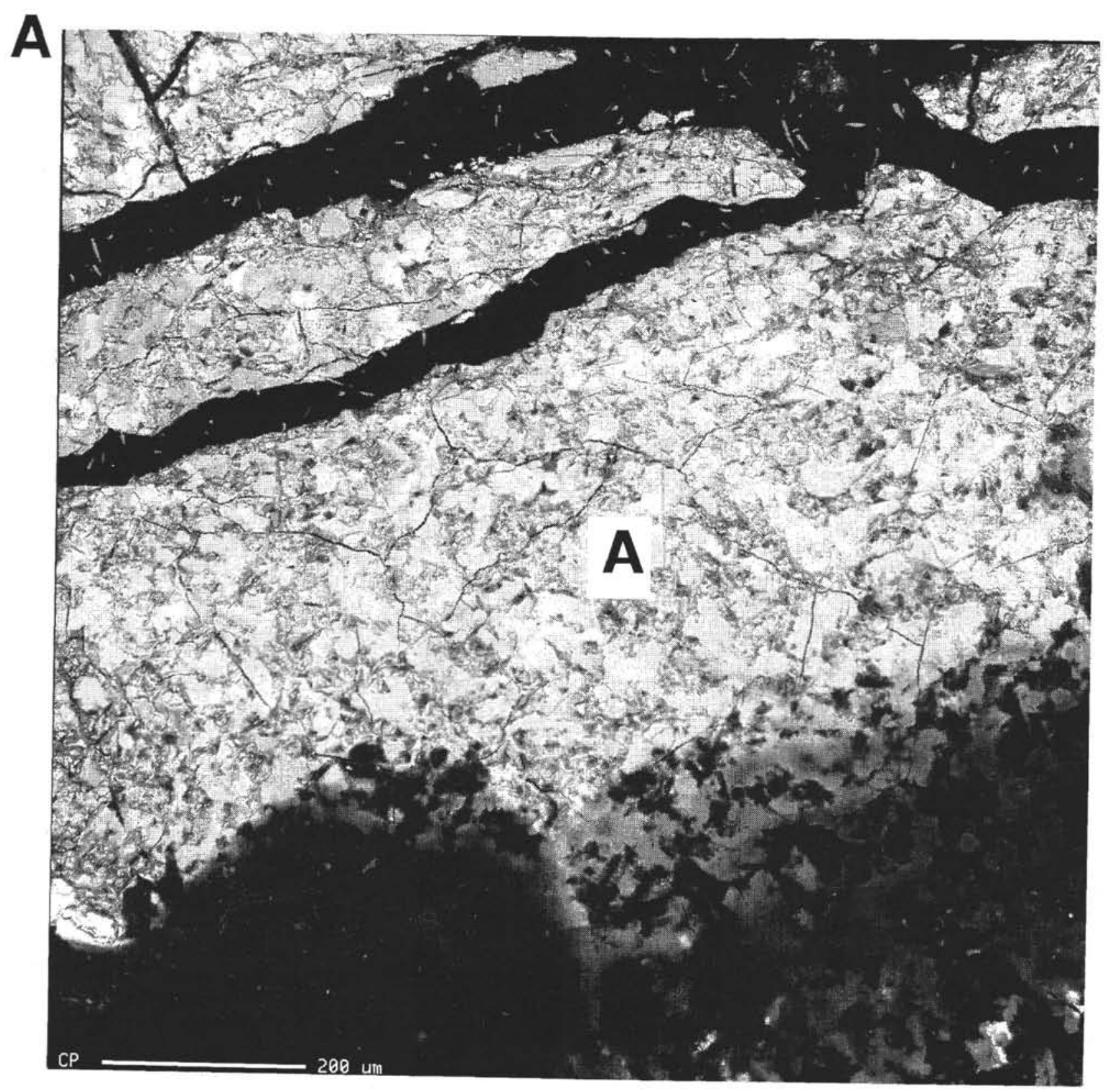

Appendix Figure B-5. BSE images of selected portior of Sample 148-896A-28R-1, 93-96 cm (Piece 18A) (440.9 mbsf) showing areas of EMP analyses. 


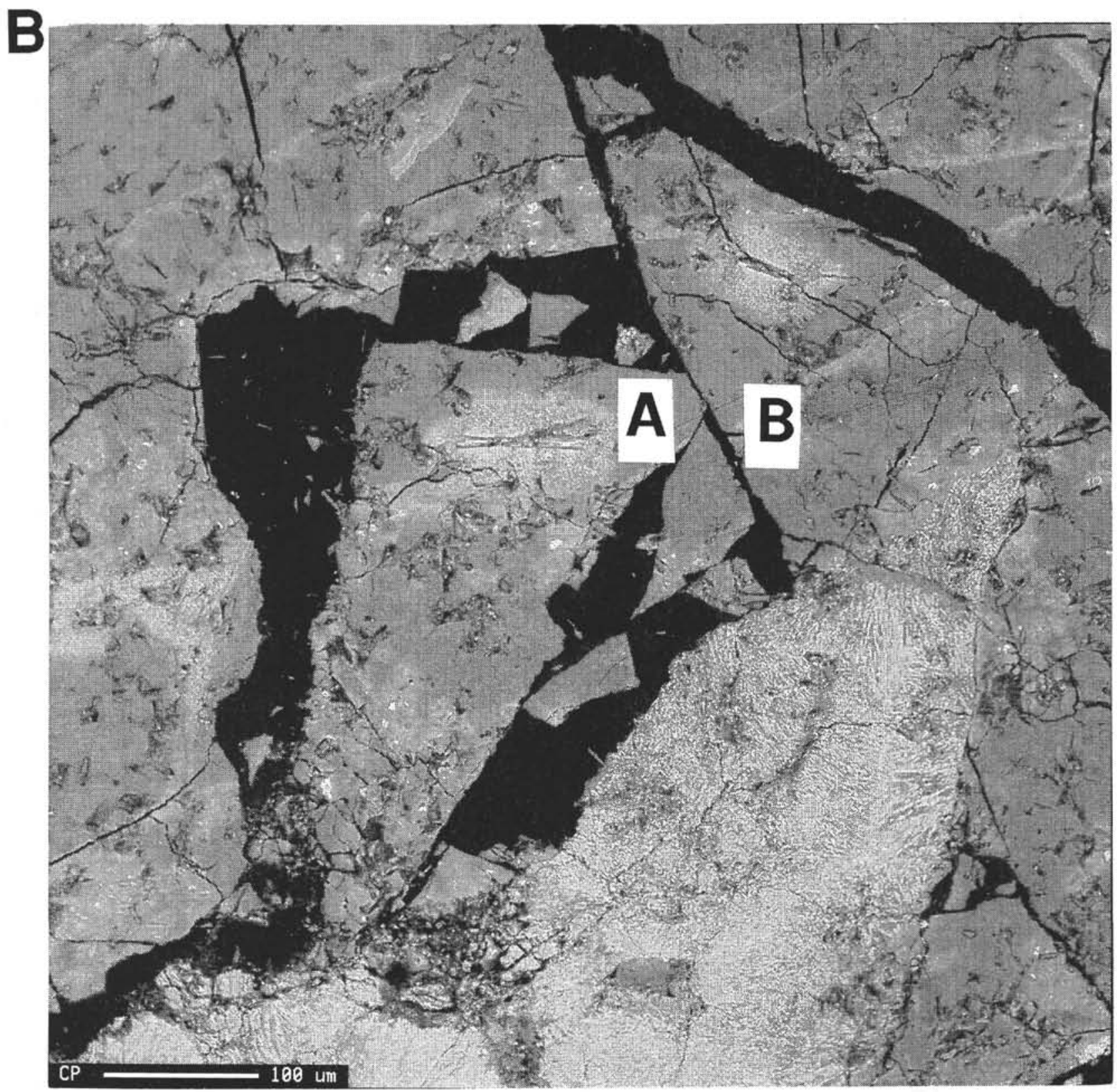

Appendix Figure B-5 (continued). 


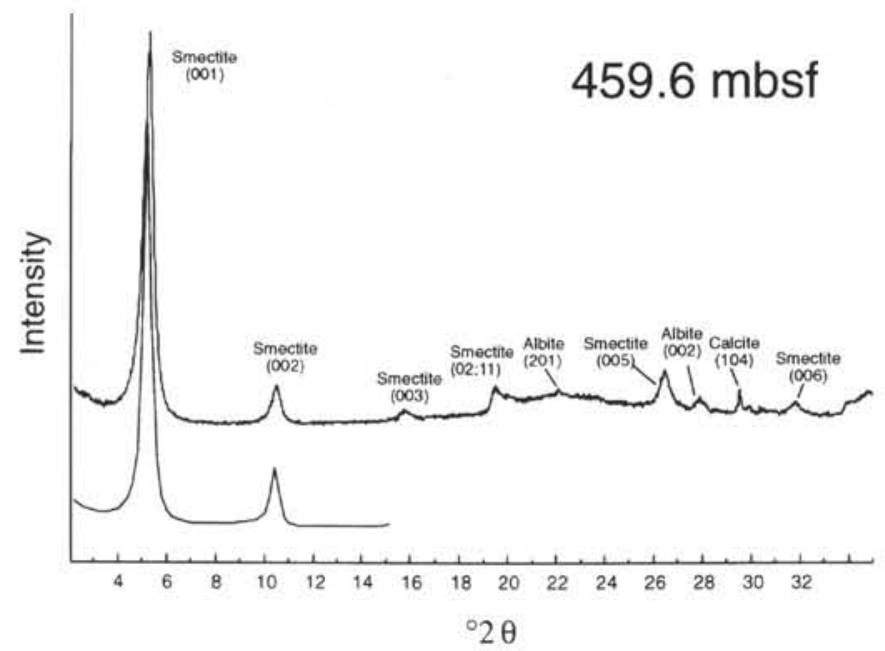

Appendix Figure B-6. XRD (CuK $\alpha$ ) pattern (top) and NEWMOD calculated diffraction pattern (bottom) for Sample 148-896A-30R-1, 40-42 cm (Piece 7) $(459.6 \mathrm{mbsf})$. 